\title{
Some graminicolous species of Helminthosporium in Finland
}

\author{
Kaiho $M \ddot{a} k$ elä \\ Department of Plant Pathology, Univensity of Helsinki
}

\begin{abstract}
This paper is part of a larger study of the fungi causing leaf-spot diseases which affect the grasses on leys in Finland. The material examined consisted of grasses growing on cultivated grassland or the borders of fields. The fresh material (c. 3770 samples) was collected at Viik and the Muddusniemi Experiment Farm of Helsinki Univensity, at Experiment Stations of the Agricultural Research Centre, the Plant Breeding Institute of Hankkija and in other localities in sounthern Finland. In addition seeds of grasses (c. 160 lots) chiefly from the State Seed Testing Station (SSTS) anci from the material (c. 40 lots) of the late Prof. Otto Valle's experiments were investigated. The last mentioned lots of the Finnish seeds (Tammisto) were produced in the USA. This study is moreover based on artificial culture and inoculation tests.

The genus Helminthosporium Link has been found to be well-represented in Finland on various grasses. Descriptions of disease symptoms, morphological chracters and general significance are given for the following species. Helminthosporium dictyoides Drechs. f. sp. dictyoides Braverman \& Graham, $H$. dictyoides Drechs. f. sp. perenne Braverman \& Graham, H. phlei (Graham) Scharif, H. siccans Drechs., H. vagans Drechs., H. tritici-repentis (Died.) Diedicke, H. sativum Pammel, King \& Bakke, H. biforme Mason \& Hughes, H. triseptatum Drechs., as well as Drechslera dactylidis Shoemaker.

The most important and widespread species are $H$. phlei on Phleum pratense L., $H$. dictyoides $\mathrm{f}$. sp. dictyoides on Festuca pratensis Huds., $H$. dictyoides $\mathrm{f}$. sp. perenne and $H$. siccans on Lolium multiflorum Lam. and $L$. perenne $\mathrm{L}$. as well as $H$. vapans on Poa pratensis L. H. tritici-repentis is at least locally common on Agropyron repens (L.) PB., whereas $H$. sativum, $H$. biforme and $H$. triseptatum were found only accidentally.
\end{abstract}

\section{Introduction}

Helminthosporium Link is a genus of Moniliales (Ainsworth 1961). More than 100 species live on graminaceous hosts, particularly the parasitic forms (DreaHSLER 1923, Luttrell 1954, 1964). According to Hughes (1959) the graminicolous species of Helminthosporium form conidia only at the conidiophore apex and produce a new apex by subterminal growth. NisIKado (1928) divided these Helminthosporium species into two subgenera: Eu-Helminthosporium, with fusiform conidia, germinating from the polar cells, and Cylindro-Helminthosporium, with cylindrical conidia, germinating from the polar cells as well as the intermediate cells. Iто (1930) classified these subgenera as separate genera, the former as Helminthosporium, the latter as Drechslera. Shoemaker (1959) gave the former a new name: Bipolaris.

In the present study the older, more common form of undivided genus Helminthoporium is used, because the new nomenclature is still not established (cf. LutTrelL 1964).

The study was based on collections of fresh material, seed tests and inoculation tests on seedlings of different grass species. The 
characteristics of the species in artificial culture were also incorporated into the work.

About 44 per cent of the total arable land in Finland is covered by grass (1210 500 hectares). This area consists mostly of temporary leys (Maataloustilastollinen Kuukausikatsaus 1969). In addition, wild grass is common throughout the country (HUULTÉN 1950, PaAtela 1953). The red clover-timothy leys are the most common type of leys cultivated in Finland. In 1951, when an extensive study of leys was made, the percentage of clover leys was 30, that of timothy, 46, and that of all other grasses, 13 (PAatela 1953). According to the survey of leys in 1966-67, the proportion of cultivated grasses had increased, being about $65 \%$ (Mukura et al. 1967). Phleum pratense L. is the most abundant sown grass in Finland, even though the importance of Festuca pratensis Huds., Dactylis glomerata L., Lolium-, Poa- and Agrostis -species is growing.

In Finland there is little knowledge of the fungi causing leaf-spot diseases on the grasses and on these seeds (cf. Brummer 1937, Ritvanen 1958, Mäkel $\ddot{A}$ 1970). There is information about the damage, to Hordeum vulgare L. caused by Helminthosporium gramineum Rabh. (Rouvala 1967), and to Avena sativa $\mathrm{L}$. caused by $H$. avenae Eidam (ReKola et al. 1970) Information on the Helminthosporium-species on grasses is scanty. According to Karsten (1884: 39) H. flexuosum Corda, syn. Brachysporium flexuosum (Corda) Sacc. was found to occur on the leaves of Aira alpina L., Glyceria angustata Fries, Poa stricta Lindeb. and Luzula hyperborea R. Br. p.p. In Finnish-produced Phleum pratense L. seeds, RitvaneN (1958) observed a Helminthosporium which was not precisely identified. The same observation was made in Denmark with a lot of seeds sent from Finland (NeErgaArd 1956). In BRumMer's (1937) study of timothy diseases, however, Helminthosporium did not appear at all.

\section{Materials and methods}

Studies on the genus Helminthosporium were carried out in $1966-70$ at the Plant Pathology Department of Helsinki University, located at Viik, Helsinki. The material examined covered the diseases that attack grasses growing on leys and the borders of fields. Observation and the collection of fungus samples was done during the period between spring thaw and the first real snowfall in autumn. In addition, samples were collected (3770 sampels) at the Muddusniemi Experiment Farm of Helsinki University in Inari, at the Experiment Stations of the Agricultural Research Centre, the Plant Breeding Institute of Hankkija, in Hyrylä, in Hämeenlinna, Iitti, and the neighbouring localities of Helsinki (Fig. 1). Microscopic slides for measuring were prepared from all samples bearing spores of Helminthosporium. In this material, 18 samples came from Agropyron repens, 1 from Agrostis stol.onifera, 28 from Alopecurus pratensis, 211 from Dactylis glomerata, 879 from Festuca pratensis, 36 from $F$. rubra, 7 from Lolium multiflorum, 93 from L. perenne, 572 from Phleum pratense, 1 from Poa annua and 66 from Poa pratensis, the total number of samples being 1911.

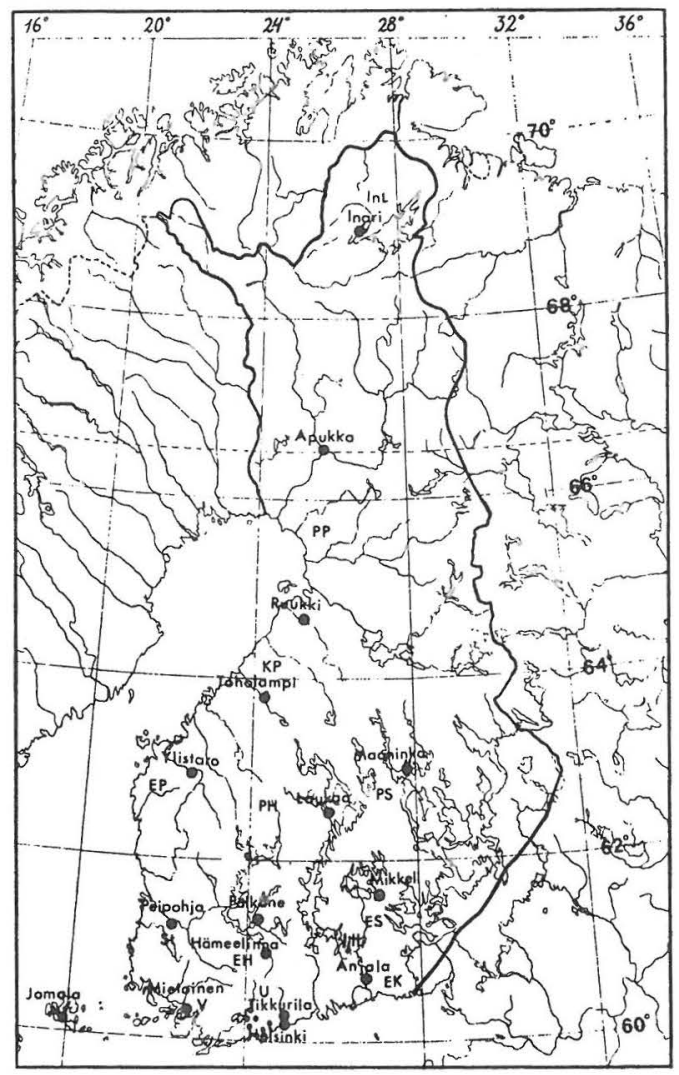

Fig. 1, Origin of the material. 
For the present study leys with the following grass species and varieties were established at Viik and at Muddusniemi in 1966-70.

Agrostis tenuis Sibth. Alopecurus pratensis L.

Foreign

Finnishi

Bromus inermis Leyss. Jokioinen, Jo 266

Dactylis glomerata $\mathrm{L}$. Tammisto, Esko, Hera

Festuca pratensis Huds. Tammisto, Paavo, Leto

F. rubra L.

Lolium multiflorum Lam.

L. perenne L.

Phleum pratense $\mathrm{L}$.

Poa pratensis L.

Highlite

Leda

Valinge, Mito

Tammisto,

Tarmo

Øtolte, Nike,
Dasas

The size of the field plots varied from 5 to $50 \mathrm{~m}^{2}$ in different years. The grasses were sown in rows $15 \mathrm{~cm}$ apart. Specimens were also collected from Professor Otto Valle's seed production experiments in which the grass species were Dactylis glomerata, Festuca pratensis, and Phleum pratense, all of them Tammisto varieties.

In addition seeds of grasses (c. 160 lots) chiefly from the State Seed Testing Station (SSTS) and from the material (43 lots) of Professor Otto Valle's experiments were investigated. The last mentioned seed lots, 21 lots came from Dactylis glomerata, 13 from Festuca pratensis and 9 from Phleum pratense, were the Finnish seeds (Tammisto) which were produced in the USA. The seeds were put into lots of $100-400$ seeds in the laboratory, and the fungi of seeds were studied by means of both germinating and sprouting experiments. The germinating experiments were carried out in incubator at a temperature of $+20-22^{\circ} \mathrm{C}$; the seeds were kept on a moist blotting paper and the development of the fungi was observed through a stereomicroscope for periods of 7, 14, 21 and 28 days. The sprouting samples were grown in small plastic pots containing sterilized sand under laboratory conditions (temperature $+15-+25^{\circ} \mathrm{G}$, relative humidity c. $60-70 \%$ ).

After the completion of the experiment (21 -28 days) the pots were kept in a moisture chamber for approximately one week, after which the fungi were examined through a microscope.

Inoculation studies on grasses were carried out under laboratory conditions. The species of grasses examined were the same as in the field trials. In addition to these the following cereals and varieties were used for certain studies.

Avena sativa L. Sisu

Hordeum vulgare L. Otra

Secale cereale L. Ensi

Triticum aestivum L. Svenno Spring wheat $\gg$

The grasses were grown in a greenhouse to a height of about $5-10 \mathrm{~cm}$. The plants were inoculated with a spore suspension prepared in distilled water with conidia produced on potato dextrose-agar (Difco). After inoculation the plants were kept in the phytothron at $+22^{\circ} \mathrm{C}$ and under illumination by day, as well as at $+15^{\circ} \mathrm{C}$ and in the dark by night from 7 to 10 days. Varying and representative materials were used for the size readings and colour descriptions of the disease symptoms. The colour descriptions were based on the classification of KORNERUP and WANSGHER (1967). Conidia produced in natural infectations were chiefly examined. The slide of the fungus material was preserved in lacticacid, and lactophenol solution $\left(\mathrm{H}_{2} \mathrm{O} 20 \mathrm{~g}\right.$, phenol $20 \mathrm{~g}$, lactic-acid $40 \mathrm{~g}$, glycerin $20 \mathrm{~g}$, trypanblau $0.05 \mathrm{~g}$ ) where the conidia and conidiophores were also metsured and photographed. For each sample from between (5) 10 and 100 conidia were measured. The minimum, average, and maximum measurements were recorded.

\section{Climate and weather}

An important factor contributing to the frequent occurrence of fungi in Finland is evidently the Finnish climate with its long, humid spring and autumn as well as its short and cool summer. The length of the thermal spring $\left(0^{\circ}-10^{\circ} \mathrm{C}\right)$ varies from 45 to 65 days, that of the thermal autumn $\left(10^{\circ}-\right.$ $0^{\circ} \mathrm{C}$ ) from 45 to 85 days. The length of the growing season is from 100 to 180 days. The monthly precipitation during the growing season varies from 35 to $80 \mathrm{~mm}$, and is lower early in the season than in the autumn (KOLKKI 1966). 
Year 1966. Precipitation during the growing season in most parts of the country was higher than the average. Temperatures were below the normal.

Year 1967. The weather during the growing season was, as a rule, rainier than normal. Temperatures in May and September were above, in other months of the growing season below, the average. November was exceptionally warm.

Year 1968. During the entire growing season, the weather in central and eastern Finland was rainier than normal, elsewhere it was the same as, or lower, than normal. Temperatures throughout the country were below the mean, only June in southern Finland was warm.

Year 1969. Precipitation during the growing season, particularly in June, July, August and October was considerably lower than the average, especially in southwestern Finland and upper Pohjanmaa. The spring was cool while the whole summer was extraordinarily warm.

Year 1970. Precipitation throughout the country varied considerably in May, was lower than normal in June and August, and higher than normal in July. Temperatures in May were normal, in June much higher than normal throughout the country. In Lapland July and August were also warmer than the average. In Southern and Central Finland temperatures were normal in July, below the normal in August.

\section{Results}

Helminthosporium dictyoides Drechsler J. Agric. Res. 24: 679, 1923. Syn. Drechslera dictyoides Shoemaker Canad. J. Bot 37: 881, 1959. Braverman and Graham (1960) divided this species into two formas speciales: $H$. dictyoides Drechs. f. sp. dictyoides. Sclerotial bodies produced in culture; causing a net-blotch and blotch on leaves of Festuca elatior and $F$. arundinacea; $H$. dictyoides Drechs. f. sp. perenne. No sclerotial bodies were produced in culture; blotching was produced on leaves of Lolium perenne and L. multiflorum.

Helminthosporium dictyoides Drechs. $f$. sp. dictyoides Braverman \& Graham.

\section{On Festuca pratensis}

The fungus frequently attacks Festuca pratensis in the USA (Dreghsler 1923, Sprague 1950, Graham 1955, Braverman \& Graham 1960), in Canada (Shoemaker 1962) in Britain (Dennis \& WAKefield 1946), in Germany (Mürlee 1953, Frauenstein 1968), in Switzerland and in Denmark (Амmon 1963). In an inoculation test, in which the fungus was isolated from $F$. pratensis, only this grass species was infected according to GraHAM (1955) and to Ibrahim and Threlfall (1966), while according to Ammon (1963), the disease symptoms appeared on Bromus inermis, Dactylis glomerata, Festucc pratensis and Lolium multiflorum. In the studies of FaUenstein (1968) 32 Festuca-species were inoculated; of these 30 Festuca-species were infected; the species affected were $F$. pratensis, $F$. rubra and $F$. ovina, as well as 6 Lolium-species among $L$. perenne and L. multiflorum.

In the present study $H$. dictyoides f. sp. dictyoides was found on Festuca pratensis from different localities ranging from Helsinki to Inari (Fig. 1). $80 \%$ of the material studied (c. 1100 samples) was infected by the fungus. Disease symptoms and viable spores of the fungus were found on the leaves during the period between early spring (28. III. 1968), often immediately after spring thaw, and late autumn (24. XI. 1967). Conidia were most abundant in mid and late summer. The fungus caused brown leaf spots surrounded by a chlorotic zone (Fig. $2 \mathrm{~A}, \mathrm{~F}$ ), withering leaf tips and borders (Fig. 2 B, G) (cf. Dickson 1947, Frauenstein 1968), as well as indefinite net-blotch (Fig. 2 D, E) (cf. Drechsler 1923, Shoemaker 1962). The centres of the lesions were sepia - chocolate - coffee brown in colour. The margin was butter yellow to cream coloured; often the margin was lacking. The size of lesions collected from different localities (about 1100) was (0.5) 9.3 (80) mm long, (0.5) 1.8 (4) $\mathrm{mm}$ wide. Conidiophores grow singly or in groups, simple, erect and short; the are dark grey to brownish grey in colour (Fig. $4 \mathrm{~A}$, D); in moist conditions conidiophores germinated very rapidly, forming long mycelia. Conidia are nearly colourless at first, later light yellowish grey - light yellowish brown to dark grey. Conidia are widest near the basal septum. The basal cell is short and 

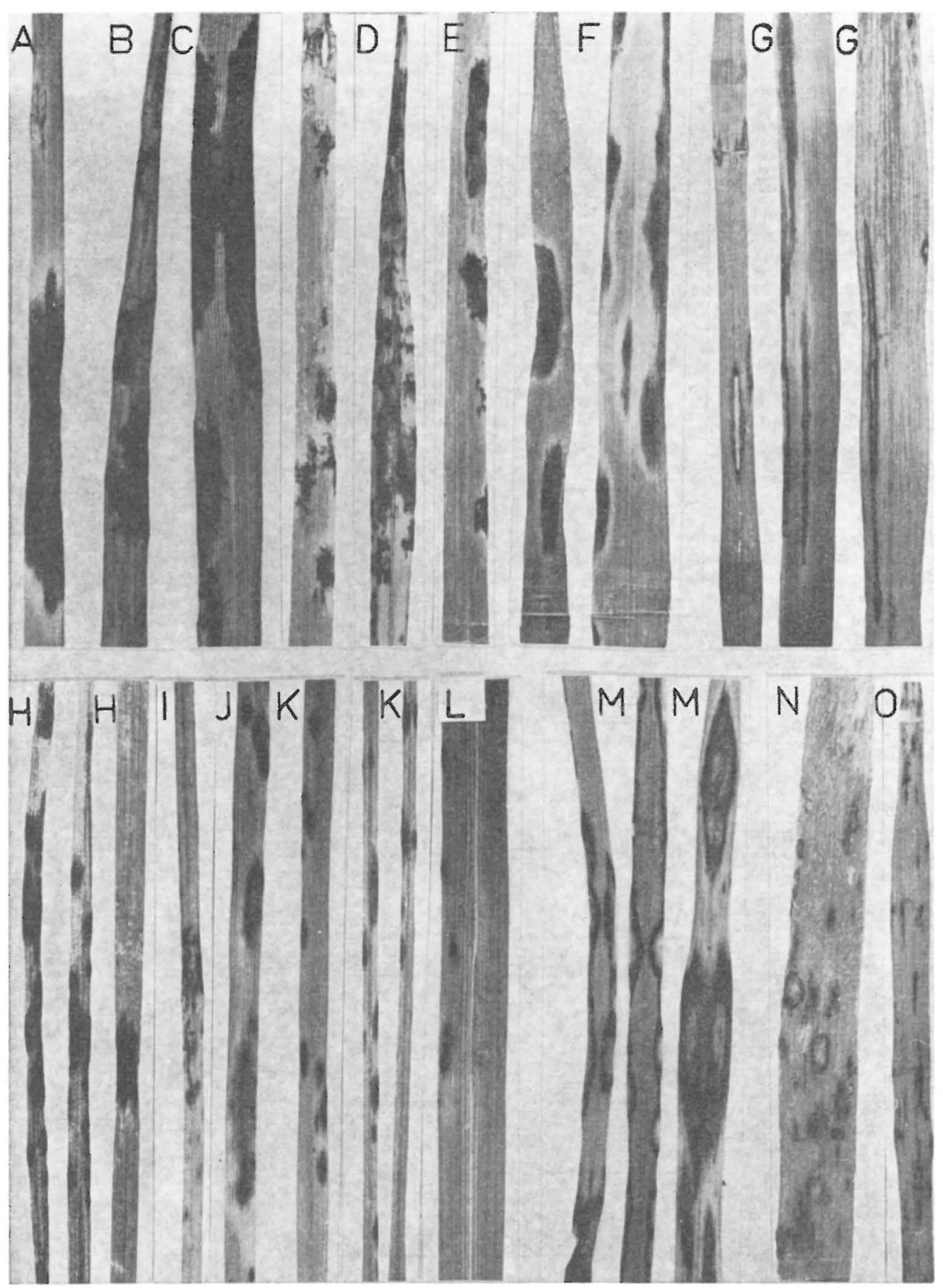

Fig. 2. Lesions on leaves caused by Helminthosporius species. A-F, H: H. dictyoides $\mathrm{f}$. sp. dictyoides, $\mathrm{A}-\mathrm{F}$ : on Fesiuca praiensis, $\mathrm{H}$ : on $i^{i}$. rubra; $\mathrm{G}$ : H. phlei on Phleum pratense; I-J: H. dictyoides $\mathrm{f}$. sp. perenne on Lolium perenne; $\mathrm{K}-\mathrm{L}$ : $H$. siccans, $\mathrm{K}$ : on $L$. perenne, $\mathrm{L}$ : on $L$. multiflorum; M: H. vagans on Poa pratensis; N-O: H. tritici-repentis on Agropyron repens. $\mathrm{x} 1$. 


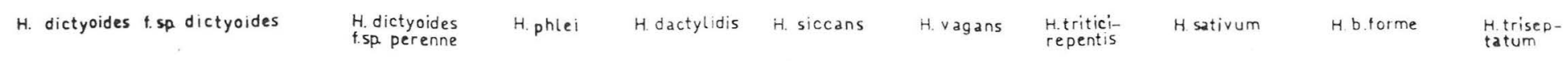
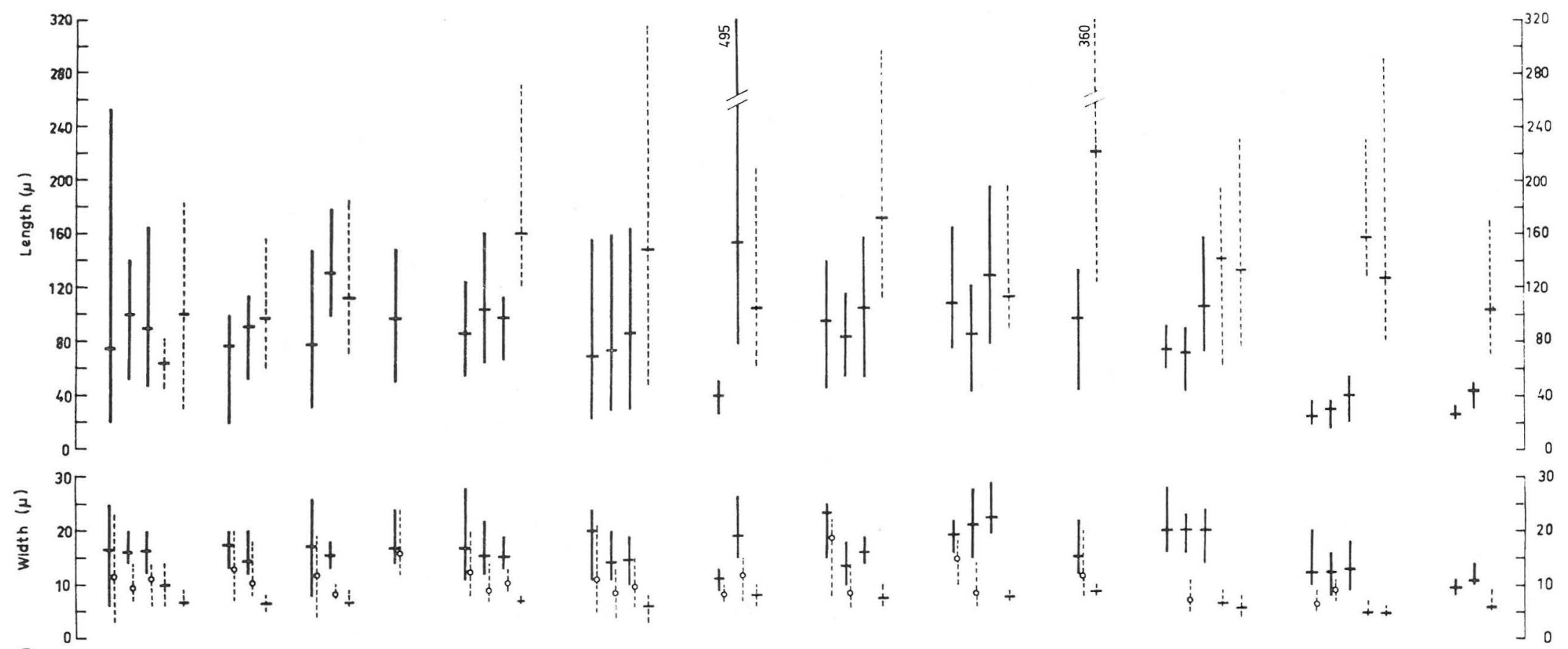

$\begin{array}{ll}\text { i } & 20 \\ \text { in } & \\ \text { ஸे } & 10\end{array}$

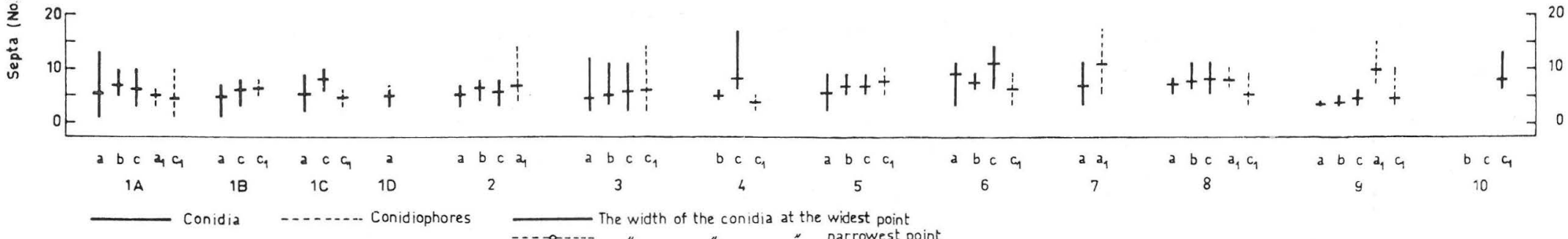

Fig. 3. Size of conidia and conidiophores of the Helminthosporium species, a, a1: on leaves from fields, b: on seed, c, c1: on inoculated seedlings. 1A: on Festuca

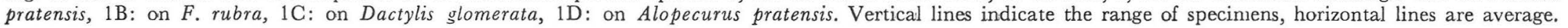




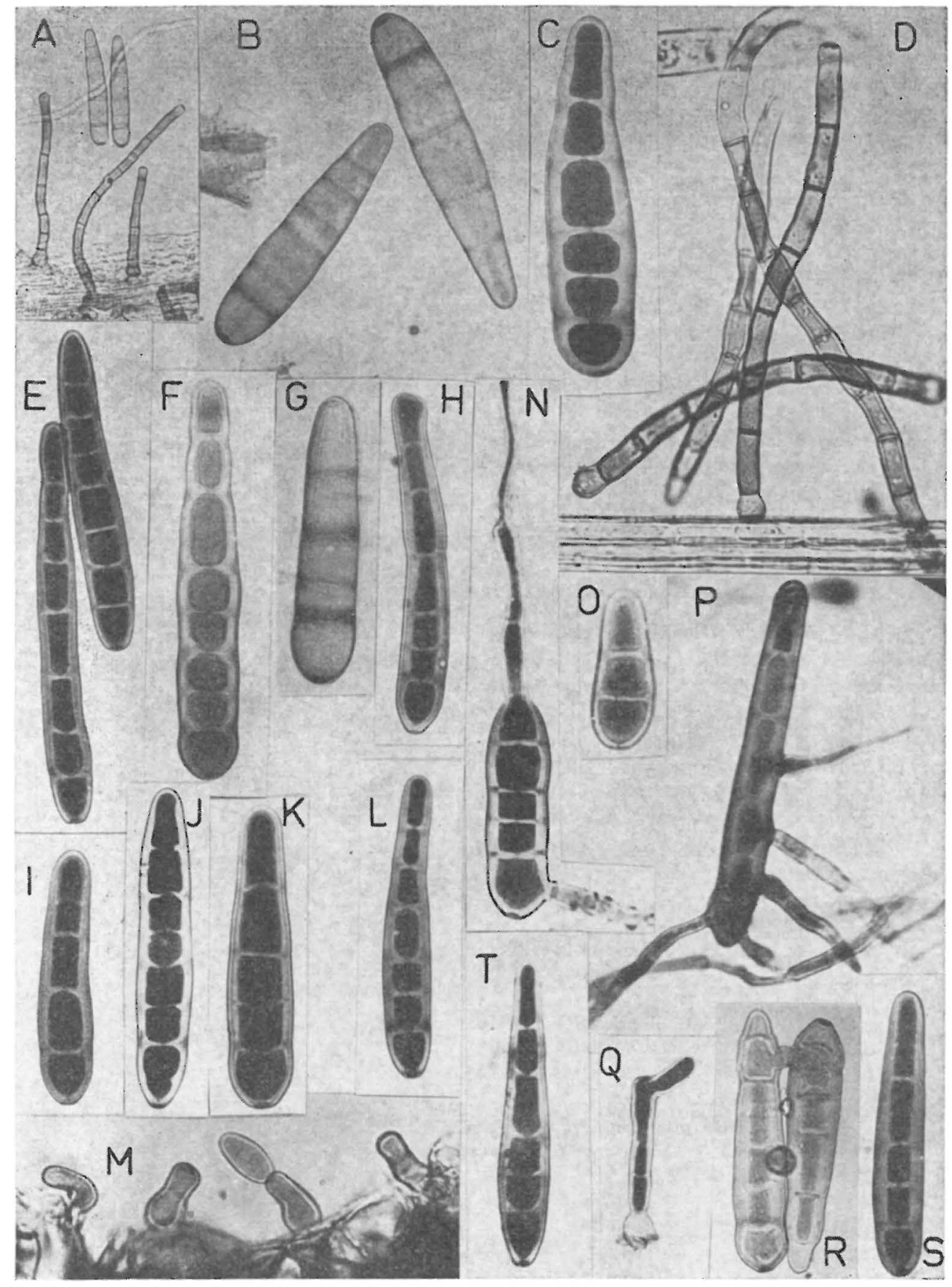

Fig. 4. Conidia and conidiophores of Helminthosporium dictyoides f. sp. dictyoides. A-P: on Festuca pratensis, Q-S: on F. rubra, T: on Dactylis glomerata. A-B, D-E: on seeds, C, D-T: on leaves from fields. A, D: 'Tammisto' 30625, 191968, Finnish, B: 'Leto' 1967, Commercial seed, C: Helsinki 27. IX. 1967, 'Paavo', E: 'Paavo', Jokioinen, 1967, F-G: Helsinki 27. IX. 1966 (F: 'Paavo', G: 'Leto'), H-I: Jomala 19. VIII. 1969, J: Tikkurila 11. VI. 1969, K: 8. IX. 1969, L: Mikkeli 28. VI. 1868, M: Helsinki 20. VIII. 1969, N: Toholampi 30. VII. 1969, O: Helsinki 20. VIII. 1969, P: 8. VII. 1970 'Tammisto', Q-S: Inari 14. VII. 1969, T: Mikkeli 22. VII. 1969. $\mathrm{A} \times 150, \mathrm{~B}-\mathrm{T} \times 400$. 
Table 1. Results of the inoculation tests in the laboratory with Helminthosporium-species in 1970 (at Viik ${ }^{1)}$ )

H. dictyoides f. sp. dictyoides from

$$
\begin{aligned}
& \text { H.dict. f. sp. } \\
& \text { perenne } \\
& \text { from }
\end{aligned}
$$

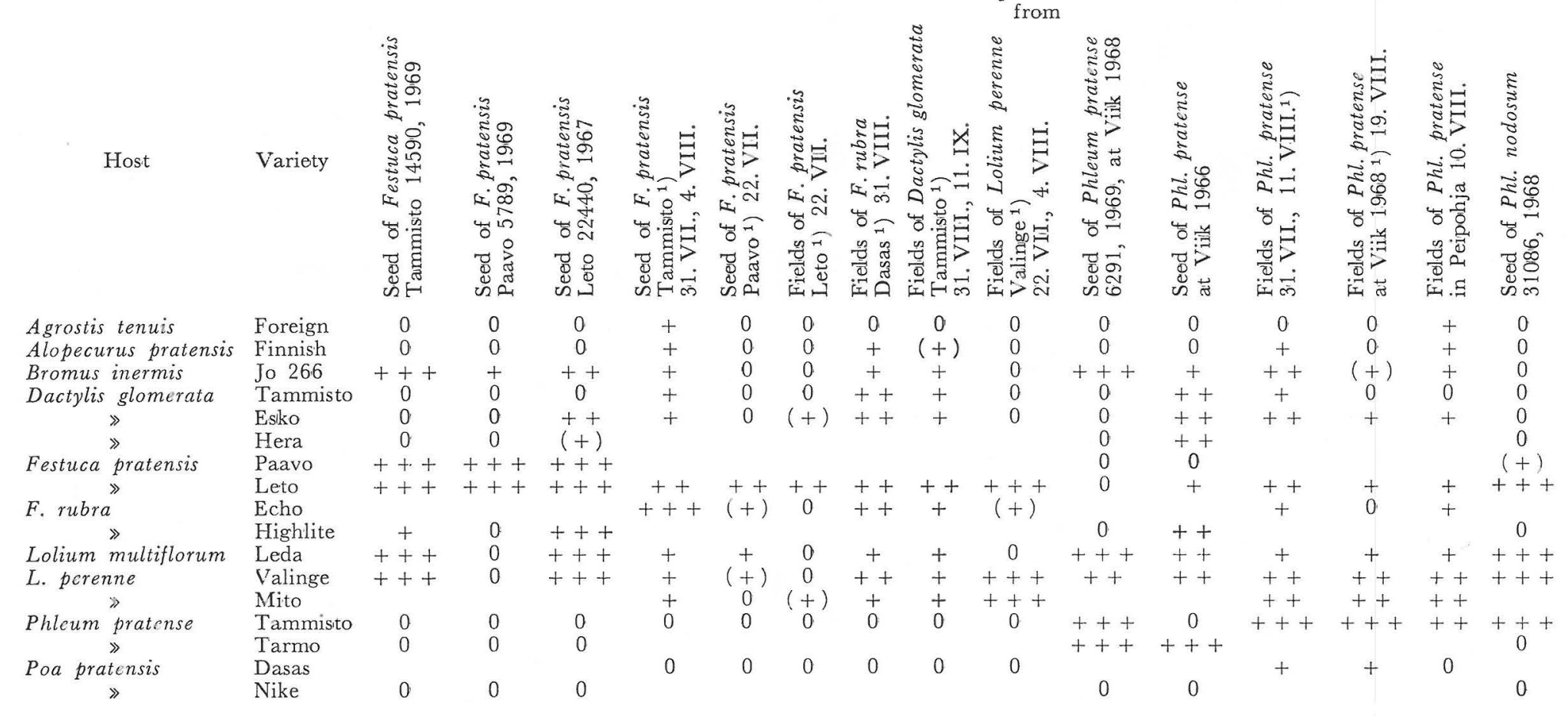


broad (Fig. 4 C, F, K) (cf. Drechisler 1923, Shoemaker 1962, Frauenstein 1968) or narrower and longer (Fig. $4 \mathrm{E}, \mathrm{J}$ ) (cf. PAUL and BARBERY 1968). The spores tapered uniformly to an apical segment, germinating from all segments, mostly from the end segments (Fig. $4 \mathrm{~N}, \mathrm{P}$ ). The formation and size of the conidia (about 1170) averaged (20) 75.1 (255) $\mu$ long, (6) 16.5 (25) $\mu$ wide at the widest point, (3) 11.8 (23) $\mu$ wide at the narrowest point, (1) 5.3 (13)-septa (Fig. 3, 1 A) showing little variation between the different localities and times of collection. Exceptional types of spores were also found in samples collected during early spring and late autumn. Both on seeds and on leaves from fields broader types of conidia were found side by side with narrower ones (cf. KenNETH 1958). In the present study the size of spores was greater than DreaHSLER's (1923) and Ammon's (1963) material and smaller than reported by Shoemaker (1962) and FraUeNSTEIN (1962).

All $(100 \%)$ the seed lots of Fistuca pratensis examined (24 lots, chiefly from the State Seed Testing Station) were infected by the fungus. This conresponds to $34 \%$ (range 3-86 \% of all the seeds examined. The fungus grew slowly and sparsely on the seedling and was short-lived; sclerotial bodies developed abundantly on these.

In inoculation tests on various grass species (Table 1) inoculated with conidia of $H$. dictyoides $\mathrm{f}$. sp. dictyoides produced on potato dextrose agar (many isolates from seeds and leaves from fields of Festuca pratensis), abundant conidia appeared on $F$. pratensis, moderate conidia on Bromus inermis, Lolium multiflorum and L. perenne, infrequent conidia on Festuca rubra as well as accidental conidia on Alopecurus pratensis and Dactylis glomerata. The results are confirmed by Ammon's (1963) observations in her inoculation tests.

The colony (Fig. 10, A-D) grows rapidly, at first forming a fine black strand. After 2 to 3 weeks a low greyish green - olivaceous mycelium develops on the agar surface. The rate of growth of different isolates varies. The protothecia form abundantly. The fungus is long-lived in culture.

\section{On Festuca rubra}

This species is known to be a host plant for $H$. dictyoides $\mathrm{f}$. sp. dictyoides in Germany
(FraUenstein 1968), F. rubra var. commutata Gand. (Sprague 1950), and on F. rubra (Couch \& Golf 1957) in the USA.

In this study $H$. dictyoides $\mathrm{f}$. sp. dictyoides was found on Festuca pratensis from some localities. About $15 \%$ of the material studied (c. 240 samples) was infected by the fungus. At Viik viable spores of the fungus were found on the leaves from early spring (3. IV. 1967) to late autumn (24. XI. 1967). Spores were always found in small quantity. The fungus usually caused scarce mustard tobacco brown to dark brown leaf spots surrounded by a greyish orange margin (Fig. $2 \mathrm{H}$ ). The size of lesions (about 50) was (1) 3.1 (10) mm long, (0.5) 1.0 (2) $\mathrm{mm}$ wide. Conidiophores and conidia were similar in shape and colour to those of $F$. pratensis (Fig. 4, Q-S). The size of spores was (40 spores) (19) 77.3 (99) $\mu$ long, (13) 17.4 (20) $\mu$ wide at the widest point (7) 13.2 (20) $\mu$ wide at the narrowest point, (1) 4.8 (7)-septa (Fig. 3, 1 B).

Of all the seed lots of Festuca rubra (16 lots) from the State Seed Testing Station that were examined, about $20 \%$ were infested by the Helminthosporium ( $H$. biforme and $H$. dictyoides $\mathrm{f}$. sp. dictyoides. This corresponds to only $0.4 \%$ (range $0-4 \%$ ) of all the seeds examined. The fungus grew slowly and sparsely on the seedlings.

In inoculation tests (Table 1) in which different grass species were inoculated with conidia of $H$. dictyoides $\mathrm{f}$. sp. distyoides produced on potato dextrose agar (an isolate from Festuca rubra 'Dasas', 1969 from Denmark), moderate conidia appeared on Dactylis glomerata, Festuca pratensis, F. rubra and Lolium perenne, as well as infrequent conidia on Alopecurus pratensis, Bromus inermis and L. multiflorum.

The colony (Fig. $10 \mathrm{E}, \mathrm{F}$ ) resembled that of the isolates on Festuca pratensis.

$H$. dictyoides f. sp. dictyoides were, above all, the fungus of the species Festuca (cf. Sprague 1950), especially $F$. pratensis. It was found in nearly all the samples throughout the growing season. $H$. dictyoides $\mathrm{f}$. sp. dictyoides was a seed-borne fungus; all the seed lots examined were infected. This somewhat explains its prevalence in nature, although according to PaAtela (1953) its occurrence on leys was only $3 \%$. It is found uncultivated only in Central Finland and along the coast as far north as Tornio (Hultén 1950), 
F. rubra commonly grows uncultivated throughout the country (Hultén 1950), although, according to PAATELA (1953), its occurrence on leys was under $2 \%$. The results from this study of the $H$ dictyoides species were similar to ANDERSEN's (1955, $1959)$ results on the $H$. catenarium-species.

\section{On Dactylis glomerata}

The fungus, which resembles $H$. dictyoides f. sp. dictyoides, was found on Dactylis glomerata in various localities ranging from $\mathrm{Hel}-$ sinki to Toholampi (Fig. 1). About $20 \%$ of the material studied (c. 1000 samples) was infected by the fungus. Viable conidia occurred on the leaves from the end of May to late autumn (November): in spring, they occurred later on this grass species than on the others. Spores were always found in small quantity. Sparse, irregular necrotic streaks and necrotic areas similar to those of $H$. phlei on Phleum pratense (Fig. $2 \mathrm{G}$ ) were found on the leaves. The size of lesions (about 60 ) was (5) 8.1 (17) $\mathrm{mm}$ long and (0.5) 1.3 (2) $\mathrm{mm}$ wide. Rhynchosporium orthosporum Caldwell often occurs abundantly on the leaves of $D$. glomerata. This has made it difficult to confirm the possible precence of other kinds of symptoms.

The formation and size of conidia was (about 130) (31) 77.8 (147) $\mu$ long, (8) 17.3 (26) $\mu$ wide at the widest point, (4) 11.6 (19) $\mu$ wide at the narrowest point, (2) 5.4 (9)-septa (Fig. 3, 1 C, Fig. 4 T) showing little variation between the different localities and times of collection. The size of conidia was on the average like that of $H$. dictyoides f. sp. dictyoides on Festuca pratensis (Fig. $3,1 \mathrm{~A})$.

Of all the seed lots of D. glomerata examined (about 30 lots), from the State Seed Testing Station), about $15 \%$ were infected by the Helminthosporium (H. biforme, $H$. catenarius, $H$.dactylidis, $H$. siccans; but, certainly, no $H$. dictyoides f. sp. dictyoides). This corresponds to only $0.2 \%$ (range $0-$ $2 \%$ ) of all the seeds examined. Obviously other Helminthosporium-species grew on $D$. glomerata in nature.

The colony (Fig. 10, G) resembled that of the isolates on Festuca rubra.

This confirms the conception that D. glomerata is infected in nature by the Helminthosporium-species of other grass-species. The occurrence of $D$. glomerata on leys in Finland was under $2 \%$ according to PaAtela (1953) It is almost nonexistent in the northern parts of they country (cf. Hư.TÉN 1950, PaAtela 1953).

\section{On Alopecurus pratensis}

This fungus, which resembles $H$. dictyoides f. sp. dictyoides, was found on Alopecurus pratensis from certain locality. About $14 \%$ of the material studied (c. 200 saniples) was infected by the fungus. Viable conidia occurred on the leaves from early in spring (3. IV. 1967) to late in autumn (24.XI. 1967). Spores were always found in small quantity. The symptoms of diseases on leaves were difficult to distinguish because of the simultaneously occurring spot of Rhynchosporium sp. The size of conidia (about 20) was (50) 96.5 (148) $\mu$ long, (14) 15.8-17.7 (24) $\mu$ wide, (3) 5.0 (7)-septa (Fig. 3, 1 D). The conidia were shaped like those of $H$. dictyoides f. sp. dictyoides on other grass species.

No Helminthosporium-species were found on the seeds of $A$. pratensis.

In the inoculation tests with sporesuspension of various Helminthosporium-species conidia of $H$. dictyoides $\mathrm{f}$. sp. dictyoides (from Festuca pratensis, F. rubra and Dactylis glomerata), $H$. phlei, $H$. siccans, $H$. vagans, $H$. sativum and $H$. triseptatum on Alopecurus pratensis (Tables 1-2).

Alopecurus pratensis is not cultivated; it commonly grows uncultivated only in Southern and Central Finland (Hultén 1950). These facts confirm the opinion that in nature A. pratensis is infected by the Helminthosporium-species of other grass species The few references appearing in the literature (SPRAgue 1950, Shoemaker 1962, Frauenstein 1968) also support this view.

\section{Material examined \\ Plants}

\section{On Festuca pratensis:}

A: Jomala (5 specimens); U: Kirkkonummi (2 specimens), Siuntio (1 specimen), Helsinki (643 specimens), Vihti (1 specimen), Tikkurila (58 specimens), Nummela (1 specimen); V: Mietoinen (20 specimens); EH: Hämeenlinna (6 specimens), Pälkäne ( 9 specimens); St: Peipohja (42 specimens); EK: Anjala (6 specimens); ES: Mikkeli (44 specimens); PS: Maaninka (2 specimens); PH: Laukaa (1.0 specimens); EP: Ylistaro (9 
specimens); KP: Toholampi (13 specimens); PP: Ruukki ( 3 specimens); InL: Inari ( 4 specimens); in $1966-70$; (HPP).

On Festuca rubra:

U: Helsinki (29 specimens), Hyrylä (3 specimens) ; EH: Hämeenlinna (1 specimen); St: Peipohja (1 specimen); InL: Inari (2 specimens); in 1966-70; (HPP).

\section{On Dactylis glomerata:}

A: Jomala (2 specimens); U: Espoo (1 specimen), Helsinki (149 specimens), Tikkurila (12 specimens), Hyrylä (1 specimen); V: Mietoinen (6 specimens); EH: Hämeenlinna (5 specimens), Pälkäne (1 specimen), Iitti (2 specimens); St: Peipohja (16 specimens); EK: Anjala (2 specimens); ES: Mikkeli (6 specimens); PS: Maaninka (1 specimen); PH: Laukaa (1 specimen); EP: Ylistaro (2 specimens.); KP: Toholampi (4 specimens); in 1966-70; (HPP).

\section{On Alopecurus pratensis:}

U: Siuntio (1 specimen), Helsinki (23 specimens) ; EH: Hämeenlinna (1 specimen); St: Peipohja (1 specimen); InL: Inari (2 specimens); in 1966-70; (HPP).

Seeds (Number cited are SSTS)

On Bromus inermis:

Jo 266, EH: Jokioinen 1968.

On Festuca pratensis:

Tammisto: 1967 (Commercial seed); 21264, 1967; 21266, 1967; 14591, 1969; Paavo: 31340, 1967; EH: Jokioinen 1968; 3728, 1969; 5789, 1969 ; all seed lots are produced in Finland.

On Lolium perenne:

Valinge 14601, 1969, Finnish.

Helminthosporium dictyoides Drechs. f. sp. perenne Braverman \& Graham

The species has been reported on Lolium multiflorum and $L$. perenne in the USA (Braverman \& Graham 1960), in Canada (Shoemaker 1962), in New Zealand (Latch 1966), also in Britain the disease has been known to occur on Lolium perenne since 1921 (SAMPSON \& WESTERN 1940), and in Italy (Del Vescovo 1962). According to the descriptions of many authors (SAMPSON \& Western 1940, Dennis \& Wakefièid 1946) this disease of Lolium-species is obviously caused by this fungus. In Denmark ANDERSEN (1955) described H. siccans Drechs. Mono- sporous type on Lolium-species, later (ANDERSEN 1959) regarded it to be $H$. catenarium. This fungus resembles $H$. dictyoides f. sp. perenne. Artificially infected hosts were, according to Del Vescovo (1962), Lolium perenne L., L. italicum A. Br., Festuca elatior var. pratensis Hud. and Phleum pratense as well as, according to LATch (1966), eg. $F$. arundinacea Schreb., $F$. pratensis Huds., and $F$. rubra L. subsp. commutata Gaud.

In this study $H$. dictyoides $\mathrm{f}$. sp. perenne was found on leaves of Lolium perenne. Of all the material (c. 170 samples) collected from different localities (Helsinki, Hyrylä, Peipohja, Inari) (Fig. 1) about $55 \%$ was infected by the fungus often together with $H$. siccans (cf. p. 18), the latter more commonly. The fungus overwinters with sclerotial bodies on which grow conidiophores and conidia (Fig. $5 \mathrm{H}$ ). Disease symptoms and viable conidia of the fungus were found on the leaves during the period between early spring (3. IV. 1967) and late autumn (24. XI. 1967). The fungus caused brown leaf spots surrounded by a chlorotic zone and often leaves withered from the tip downwards (Fig. $2 \mathrm{~J}$ ). Indefinite net blotch (Fig. 2 I) (cf. LATch 1966) was also caused. The centres of the lesions were sepia - coffee chocolate brown in colour. The margin was coffee brown. The symptoms of disease on Lolium perenne resemble those on Festuca pratense caused by $H$. dictyoides $\mathrm{f}$. sp. dictyoides (cf. p. 4). Te size of lessions (about 180) was (0.5) 3.2 (22) mm long, (0.5) 1.4 (5) $\mathrm{mm}$ wide. Conidiophores grow generally singly, as simple or $1-2$ geniculate, resembling a capital L (Fig. $5 \mathrm{~A}, \mathrm{I}$ ) (cf. Del Vescovo 1962); they are dark grey to brownish grey in colour. Conidia are nearly colourless at first, later light yellowish brown to dark grey. Conidia are widest near the basal septum; they are in some measure more irregular in shape (Fig. 5 C, F, J) (cf. BRAVERMAN \& Graham 1960) as well as more longlived than those of $H$. dictyoides $\mathrm{f}$. $\mathrm{sp}$. dictyoides. The size of conidia (about 100) was, (54) 85.6 (124) $\mu$ long, (11) 17.1 (28) $\mu$ wide at the widest point, (8) 12.3 (20) $\mu$ wide at the narrowest point, (3) 5.3 (7)septa (Fig. 3, 2) (cf. Latch 1966).

Of all the seed lots of $L$. perenne examined (21 lots), $86 \%$ were infected by Helminthosporium-species (H. dictyoides $\mathrm{f}$. sp. dictyoides, $H$. siccans, $H$. sativum, $H$. biforme). 


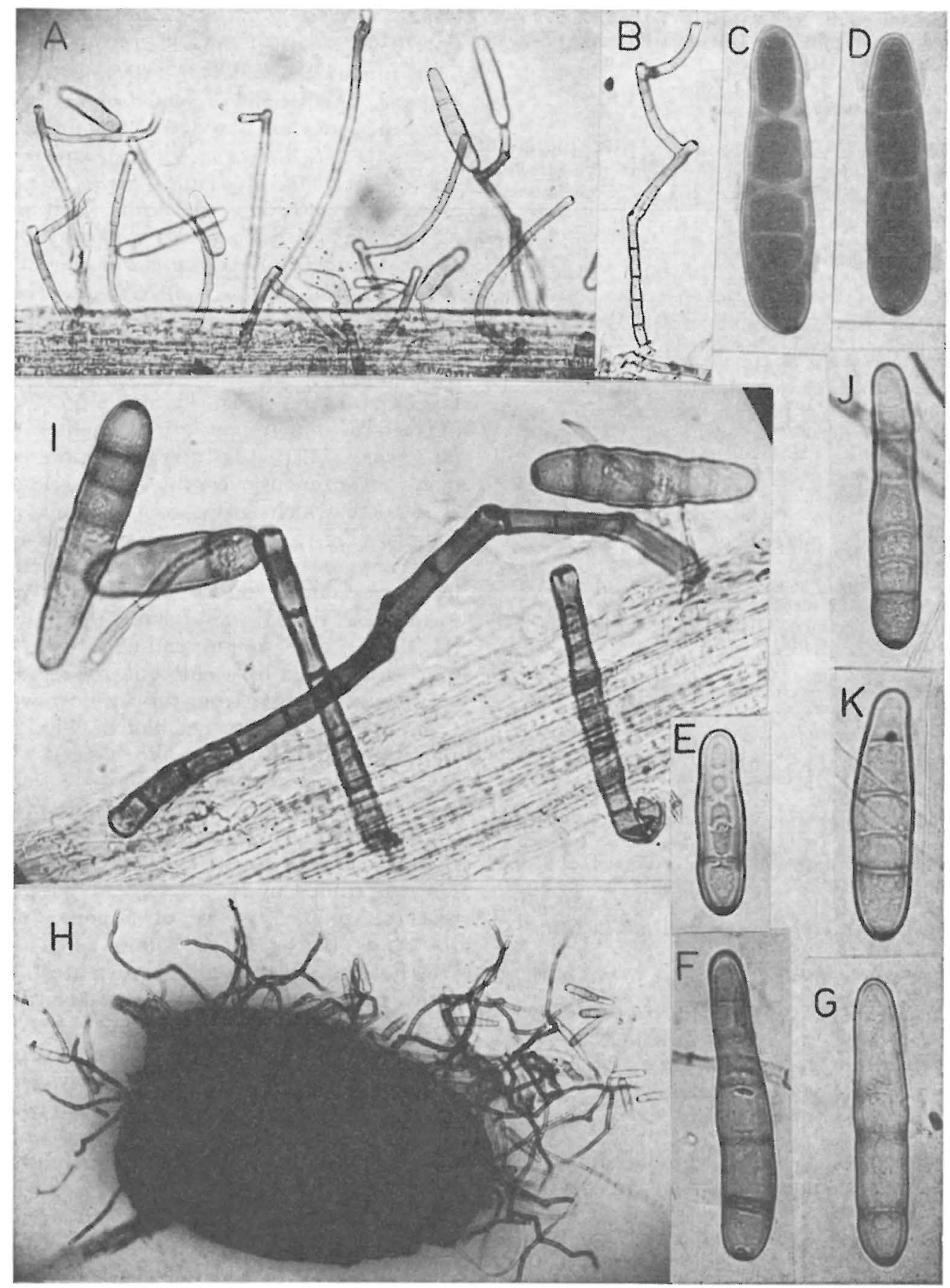

Fig. 5. Conidia and conidiophores of Helminthosporium dictyoides f. sp. perenne on Lolium perenne. A-G: on leaves from fields, I-K: on seeds. A-B: Helsinki 13. VII. 1970, C-D: 24. XI. 1967, E-G: Inari 24. VI. 1970, H: Helsinki 11. VI. 1970, sclerotium, I: 'Valinge', Viik, 1969, J-K: 'Verna' 31352, 19,68 from Poland. A-B $\times 150$, G-G, I-K $\times 400, \mathrm{H} \times 75$. 
This corresponds to $16 \%$ (range 0-72\%) of all the seeds examined. The most common species was $H$. dictyoides $\mathrm{f}$. sp. perenne.

In inoculation tests (Table 1) in which different grass species were inoculated with a fungus grown on potato-dextrose agar (two isolates from fields on $L$. perenne, Valinge at Viik), abundant conidia appeared on L. perenne and Festuca pratensis and infrequent conidia on $F$. rubra. This result is confirmed by Braverman's and Grahams's (1960), Ibrahim's and Threlfall's (1966) and Latan's (1966) studies. It differ from the research of Del Vescovo (1962).

$H$. dictyoides $\mathrm{f}$. sp. perenne were generally found as a seed-borne fungus on the seedlings of Lolium perenne. This partially explains the abundance of this fungus in natural samples, although the cultivation of the Lolium-species in Finland is insignificant (PAatela 1953) and their native occurrence is only accidental (Hultén 1950).

The colony (Fig. 10, J-L) grows rapidly, forming fine, extremely long, sparsely branched, brown strands that run deep into the agar and resemble those of $H$. dictyoides $\mathrm{f}$. sp. perenne described by Shoemaker (1962). Other colonies grow abundant lighter greyish green - olivaceous mycelium resembling those of $H$. dictyoidesf.sp. dictyoides (cf. Latch 1966). The fungus is long-lived in culture. The protothecia form moderately. This result differs from that of SHoemaker (1962).

\section{Material examined}

Plants

On Lolium perenne:

U: Helsinki (83 specimens; together $H$. siccans); Hyrylä (2 specimens); St: Peipohja (7 specimens, together $H$. siccans); InL: Inari (1 specimen).

Seeds (Numbers cited are SSTS.)

On Lolium multiflorum:

Leda: 1967 (Commercial seed).

On Lolium perenne:

Valinge: U: Helsinki, Viik, 1968; 30766, 1968, Finnish; Mito: 31662, 1968; 32464, 1968; from Denmark; Verna: Pajbjerg 31352, 1968 from Poland; 5929, 1969 from Denmark.

Helminthosporium phlei (Graham) Scharif Trans. Brit. Mycol. Soc. 44: 217, 1961. Syn.
H. dictyoides Drechsler var. phlei Graham Phytopathol. 45: 228, 1955; Drechslera phlei Shoemaker Canad. J. Bot. 37: 881, 1959. The species has been reparted on Phleum pratense e.g. in the USA (Graham 1955, Braverman \& Graham 1960, Elliott 1962), in Cianada (Shoemaker 1962), in England and in Scotland (Scharif 1961), in Switzerland (Ammon 1963), as well as on the seeds of timothy in Denmark and in Finland (SGHarif 1961). Single collections were noted on Agrostis alba and Dactylis glomerata in Canada (Soemaker 1962). According to SchafTER (1961) Festuca rubra was slightly susceptible in the inoculation tests, as was Phleum pratense. Also Festuca elatior subsp. arundinace $a$, Lolium multiflorum and L. perenne produced a few fructifications in a moist chamber. Ammon (1963) found symptoms of disease on Bromus inermis, Dactylis glomerata, Festuca pratensis, Lolium multiflorum and Poa pratensis.

In the present study $H$. phlei was found on Phleum pratense from different localities ranging from Helsinki to Inari (Fig. 1). $73 \%$ of the material studied (c. 780 samples) was infected by the fungus. The living spores of the fungus were found on the leaves during the period between early spring (3. IV. 1967) and late autumn (24. XI. 1967). Spores were most abundant in mid and late summer. The fungus produced on the leaves sparse, irregular, necrotic streaks and necrotic areas which may extend the length of the blade, or the tip of blade, up to 2/3 of blade dead (Fig. $2 \mathrm{G}$ ) (cf Graham 1955, Saharif 1961). The centres of the streaks varied from light caramel brown - camel brown - flesh coloured, the margins from dark violet brown chocolate brown to light maize yellow; often the margin was lacking. The streaks may be torn longitudinally. The size of the lesions (about 80) was (1.0) 16.2 (100) mm long, (1.0) 1.2 (8) $\mathrm{mm}$ wide. Small elongated purple eye spots described by SaHARIF (1951) were also found, but they were caused by Mastigosporium rubricosum (Dearn \& Barth.) Nannf. (Mäkelä 1970).

Conidiophores usually grow as simple, single, cylindrical and unbranched or sparsely branched; they are long and slightly bent. They are light grey to light brownish grey, to dark grey in colour (Fig. $6 \mathrm{~A}$ ). In the field conidiophores are shorter and wider than those produced in a moist chamber. 


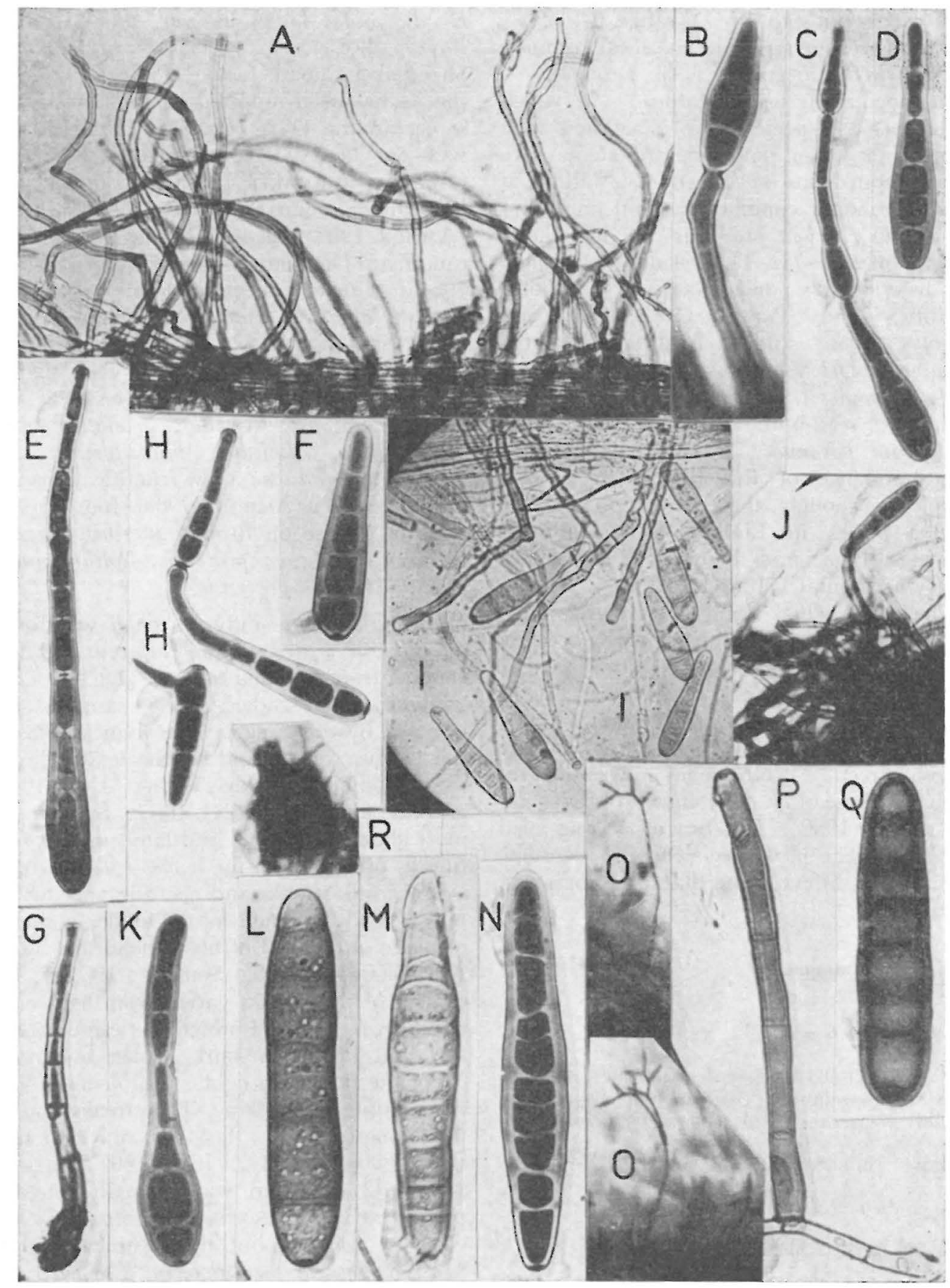

Fig. 6. Conidia and conidiophores of Helminthosporium phlei, A-K: on Phleum pratense, those of $H$. vagans, L-R: on Poa pratensis. A-G, L-N: on leaves from fields, H-K, P: on seeds, Q-R: on Potato dextrose agar. A, D: Hyrylä 29. V. 1970, B: Helsinki 10. VI. 1968, C: 2. VII. 1970, E: 8. VII. 1970, F: Hämeenlinna 11. V. 1968, G: Anjala 18. VII. 1968, H: 'Tammisto' 1969, Finnish, I : 27376, 1967, Pori, J: 31797, 1968, Finnish, sclerotium, K: 'Tammisto' 32076, 1968, Finnish, L-M: 'Nike', 1968, Commercial seed, N: Helsinki 17. V. 1968, O: 25. V. 197.0, P: 'Golf', 31066, 1967, from Sweden, R: a protothecium. A $\times 150, B-H, K-Q \times 400, I-J \times 200, O, R \times 20$. 
Conidia are subhyaline, light grey to light yellowish brown. The conidia are basically clublike in form. They are usually widest at the second cell and distinctly tapered to a narrow, hemielliptical apex (Fig. $6 \mathrm{~B}, \mathrm{D}, \mathrm{E}$, $\mathrm{K})$. Secondary conidia often form directly on the spore apex (Fig. $6 \mathrm{C}, \mathrm{H}$ ). The size of conidia (about 650) is (22) 68.9 (156) $\mu$ long, (11) 15.2 (24) $\mu$ wide at the widest point, (5) 11.1 (21) $\mu$ wide at the narrowest point, (2) 4.7 (12)-septa (Fig. 3, 3) (cf. Graham 1955). Conidia of $H$. phlei were shorter and thicker than those observed by Scharif (1961). Cionidia of $H$. phlei were smaller than those of $H$. dictyoides. (Fig. 3, 1 and 3 ).

Of all the seed lots of Phleum pratense examined (26 lots, chifely from the State Seed Testing Station), about $73 \%$ were infected by the fungus. This corresponds to $4 \%$ (range $0-14 \%$ ) of all the seeds examined. The fungus grew rapidly on the seedling and abundant conidiophores and conidia as well as sclerotia(Fig. $6 \mathrm{~J}$ ) developed on these.

In inoculation tests (Table 1) in which different grass species were inoculated with conidia of $H$. phlei produced on potato dextrose agar (many isolates from seeds and leaves from fields), abundant conidia appeared on Phleum pratense, moderate conidia on Dactylis glomerata, Lolium multiflorum and L. perenne, infrequent conidia on Bromus inermis and Festuca pratensis, as well as accidental conidia Agrostis tenuis, Alopecurus pratensis and $F$. rubra. This result differs from the studies of SaHarif (1961) as well as Ibrahim and Threlfall (1966) but is close to that of Ammon (1963).

$H$. phlei occurred only on Phleum pratense; it was commonly found on leaves of this grass, though not always in abundance. The same may be said of the seeds of timothy (cf. Ritvanen 1958). In Finland timothy is the most important by grass; according to Paatela (1953), its occurrence was $95 \%$.

$H$. dictyoides (cf. p. 9) spores were found to some extent on Phl. pratense leaves in nature. Also, in inoculation tests in which the isolate was from $F$. pratensis, $H$. dictyoides spores developed, though in small quantity, on Phl. pratense leaves and conversely. This is confirmed by Ammon (1963). However, according to Graham (1955) and Scharif (1961) H. phlei derived from Phl. pratense did not infect $F$. pratensis.
$H$. phlei were generally found as a seedborne fungus on the seedlings of Phleum pratense.

The colony (Fig. 11, A-D) grows rapidly, forming dark grey, low. dense mycelium. The margin is often light grey. The cultures are long-lived.

\section{Material examined \\ Plants:}

\section{On Phleum pratense:}

U: Kirkkonummi (6 specimens), Espoo (3 specimens), Siuntio ( 3 specimens), Helsinki (477 specimens), Vihti (1 specimen), Lohja (1 specimen), Tikkurila (2.2 specimens), Nummela (1 specimen), Hyrylä (4 specimens), Mäntsälä (1 specimen); $\mathrm{V}$ : Mietoinen (2 specimens); EH: Hämeenlinna (14 specimens), Iitti (2 specimens); PH: Ruovesi (1 specimen), Parkano (1 specimen); St: Peipohja (15 specimens); ES: Mikkeli ( 6 specimens); KIP: Toholampi (5 specimens); PP: Ruukiki (6 specimens); KmL: Rovaniemi (1 specimen); InL: Inari (5 specimens); in 1966-70 (HPP).

Seeds (Numbers cited are SSTS)

\section{On Phleum pratense:}

Tammisto 1967, 19.69 (Commercial seed); 31797, 32.076, 1968; PK: Tohmajärvi 6291, 1969; EP: Seinäjoki 8525, 1969; U: Viik 1966, 1968; Tarmo, EH: Jokioinen 1967, 1968; 38081, 1967; St: Pori, native 27376, 1967; Solf 26885, 1967 from Sweden; Omnia 23353, 1968 from Sweden.

\section{On Phleum nodosum:}

31086, 1968 from Britain.

Helminthosporium siccans Drechsler J. Agric. Res. 24: 682, 1923. Syn. H. siccans Drechsl. Polysporous type Andersen Friesia 5: 87, 1955; Drechslera siccans Shoemaker Canad. J. Bot. 37: 881, 1959. The species is common on Lolium multiflorum and L. perenne in the USA (Dreahsler 1923, Sprague 1950, Braverman \& Graham 1960) in Canada (Shoemaker 1962), in Wales and England (SAmpson \& Western 1940), in Scotland in 1932 (Dennis \& Foister 1941-42, Dovaston 1948), in Germany (Mühle 1953, Frauenstein 1968), in Switzerland (АMmon 1963), in Denmark (ANDERsen 1955) and in New Zealand (LATch 1966). The fungus reportedly infects Festuca pratensis (SAMPSON \& Western 1940, ANDERSEN 1955, Braverman \& Graham 1960). The species occurs also on seeds of Dactylis glomerata, Fectuca pratensis, F. rubra, Lolium multiflorum, L. pe- 


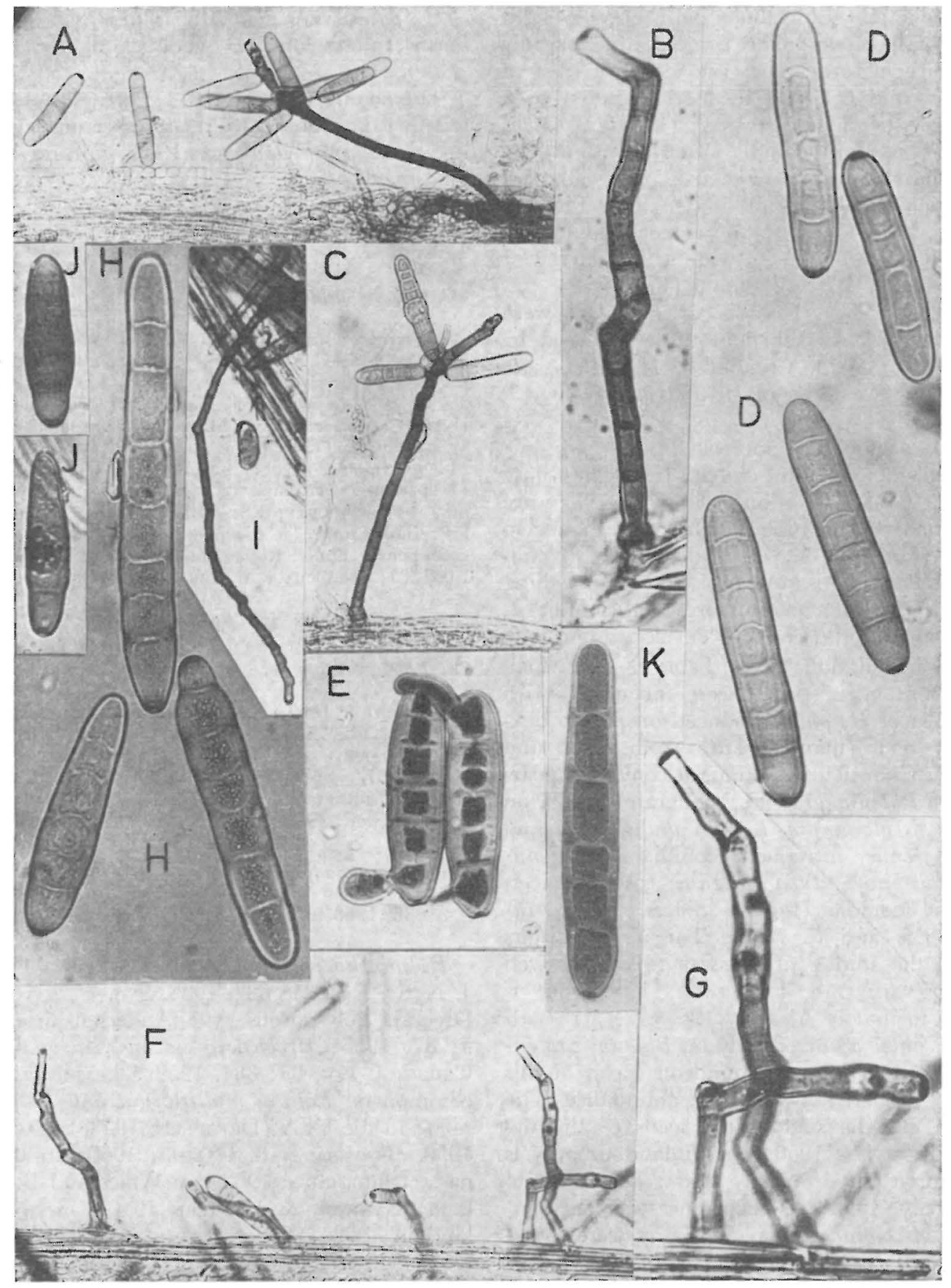

Fig. 7. Conidia and conidiophores of Helminthosporium siccans, A: on Lolium perenne, B-E: on Festuca pratensis, those of. $H$. dactylidis F-K: on Dactylis glomerata. A-D, F-J: on seeds, E, K: on leaves from fields. A: Terpas 26417, 1968 from Denmark, B: Paavo 5789, 19.68, Finnish, G-D: Ötofte 22239, 1968, Foreign, E: Mietoinen 5. VI. 1969, F-H: TSTO 6075, 1969, Finnish, H-J: Fala 26870, 1968 from Poland, K: Helsinki 10. X. 19.67. A, C, F, I × 150, B, D-E, G-H, $\mathrm{J}-\mathrm{K} \times 400$. 
Table 2. Results of the inoculation tests in the laboratory with Helminthosporium-species in 1970 (at Viik ${ }^{1)}$ )

\begin{tabular}{|c|c|c|c|c|c|c|c|c|c|c|c|c|c|}
\hline & & $\begin{array}{l}\text { Drechslera } \\
\text { dactylidis } \\
\text { from }\end{array}$ & & $\begin{array}{l}\text { H. siccans } \\
\text { from }\end{array}$ & & $\begin{array}{r}\text { H. va } \\
\text { fro }\end{array}$ & ans & $\begin{array}{l}\text { H. tritici- } \\
\text { repentis } \\
\text { from }\end{array}$ & $\begin{array}{l}\text { H. sa } \\
\text { fr }\end{array}$ & um & $\begin{array}{l}\text { H. } b i \\
\text { frc }\end{array}$ & & $\begin{array}{l}\text { H. tri- } \\
\text { septatum } \\
\text { from }\end{array}$ \\
\hline Host & Variety & 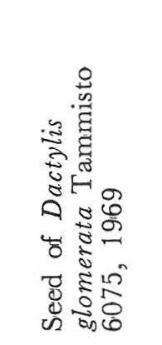 & 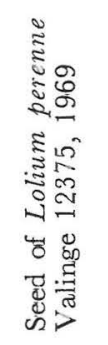 & 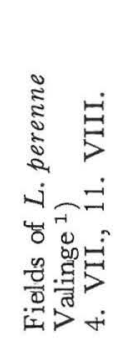 & 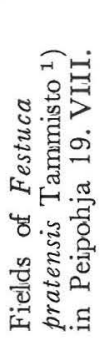 & 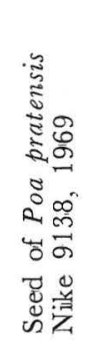 & 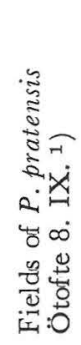 & 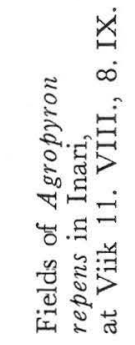 & 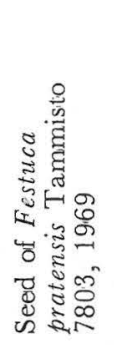 & 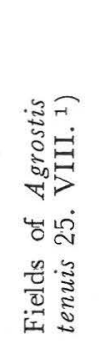 & 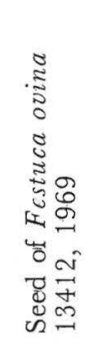 & 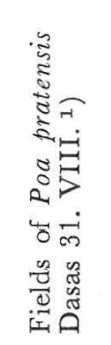 & 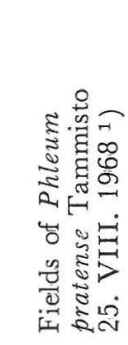 \\
\hline grostis tenuis & Foreign & 0 & 0 & 0 & 0 & 0 & 0 & 0 & + & + & 0 & 0 & + \\
\hline Alopecurus pratensis & Finnish & 0 & 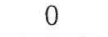 & 0 & + & 0 & $(+)$ & 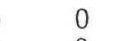 & . & T & 0 & 0 & + \\
\hline Bromus inermis & Jo 266 & +++ & $++t$ & + & +++ & +++ & $(+)$ & 0 & $+(+)$ & +++ & $+t+$ & 0 & +++ \\
\hline Dactylis glomerata & $\begin{array}{l}\text { Tammisto } \\
\text { Esko }\end{array}$ & $\begin{array}{l}+++ \\
+++\end{array}$ & 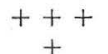 & $\begin{array}{l}+ \\
+\end{array}$ & $\begin{array}{l}0 \\
+\end{array}$ & $\stackrel{+}{+}+$ & $\begin{array}{l}0 \\
0\end{array}$ & $\begin{array}{l}0 \\
0\end{array}$ & $\begin{array}{l}+ \\
+ \\
++\end{array}$ & $\begin{array}{c}+++ \\
(+)\end{array}$ & $\begin{array}{l}+ \\
+\end{array}$ & $\begin{array}{l}0 \\
0\end{array}$ & $\begin{array}{l}++ \\
++\end{array}$ \\
\hline$\gg$ & Hera & $\begin{array}{c}++ \\
+\end{array}$ & +++ & & & $\begin{array}{c}+++ \\
+\end{array}$ & & & $\begin{array}{l}++ \\
++\end{array}$ & & + & & \\
\hline Festuca pratensis & Paavo & 0 & ++ & ++ & & 0 & & & + & & + & & \\
\hline F. rubra” & $\begin{array}{l}\text { Leto } \\
\text { Echo }\end{array}$ & +++ & ++ & $\begin{array}{l}+ \\
++\end{array}$ & $\begin{array}{l}+ \\
++\end{array}$ & 0 & $\stackrel{+}{0}$ & $\begin{array}{l}0 \\
0\end{array}$ & ++ & $\begin{array}{l}+++ \\
++\end{array}$ & +++ & $\begin{array}{c}(+) \\
0\end{array}$ & $\begin{array}{l}++ \\
+\end{array}$ \\
\hline$\gg$ & Highlite & +++ & + & & & 0 & & & $(+)$ & & + & & \\
\hline Lolium multiflorum & Leda & +++ & ++ & 0 & ++ & +++ & 0 & 0 & +++ & +++ & +++ & 0 & +++ \\
\hline L. perenne & Valinge & +++ & +++ & + & $+(+)$ & +++ & $(+)$ & 0 & +++ & ++ & ++ & 0 & +++ \\
\hline Phleum pratense & $\begin{array}{l}\text { Mito } \\
\text { Tammisto }\end{array}$ & 0 & + & + & $\begin{array}{l}++ \\
+(+)\end{array}$ & 0 & 0 & 0 & + & ++ & + & $\begin{array}{c}+1 \\
+\end{array}$ & $\begin{array}{c}++ \\
(+)^{+}\end{array}$ \\
\hline & Tarmo & + & + & & & $++t$ & & & ++ & & + & & \\
\hline Poa pratensis & Dasas & & & 0 & 0 & & + & 0 & & $(+)$ & & +++ & + \\
\hline 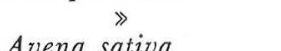 & Nike & ++ & ++ & 0 & & ++ & & 0 & + & + & ++ & & $+t$ \\
\hline Hordeum vulgare & Otra & & & 0 & & & & 0 & & +++ & & & + \\
\hline Secale cereale & Ensi & & & 0 & & & & 0 & & $++t$ & & & + \\
\hline Triticum aestivum & Svenno & & & + & & & & 0 & & +++ & & & +++ \\
\hline$»$ & & & & + & & & & 0 & & ++ & & & ++ \\
\hline
\end{tabular}


renne and Poa trivialis in Denmark (ANDERSEN 1955).

According to Ammon (1963) in inoculation tests the typical disease symptoms appeared on Lolium-species and also on Bromus mollis, Dactylis glomerata, Festuca arundinaceae, $F$. pratensis, $F$. rubra subsp. commutata, whereas FraUENSTEIN (1968) observed it on $F$. pratensis only.

In this study $H$. siccans was found on Lolium perenne from Helsinki and Peipohja (Fig. 1). The fungus occurred together with $H$. dictyoides sp. perenne, although the latter appeared more rarely. $H$. siccans also grows on Festuca pratensis in nature together with $H$. dictyoides $\mathrm{f}$. sp. dictyoides, although the latter appears much more rarely. The fungus has been found in Helsinki, Mietoinen and Peipohja (Fig. 1). The conidiophores and conidia of both fungi were often found growing on the some leaf. The viable conidia of the fungus was found on the leaves during the period between early spring (3. IV. 1967) and late autumn (24. XI. 1967). Spores were most amundant in mid and late summer. The fungus produced sparse, small, oval, chocolate to sepia brown spots on the leaves (Fig. 2, K-L) (cf. Dickson 1947, Frauenstein 1968). The size of the spots (about 50) was (0.5) 2.4 (22) $\mathrm{mm}$ long, (0.5) 1.2 (5.0) $\mathrm{mm}$ wide. On the leaves of $L$. multiflorum sparse spots occur only in late summer. $H$. siccans was found on this species in Helsinki and Inari. About $35 \%$ of the limited material (c. 20 samples) was infected by the fungus. The conidiophores grow singly or in groups of 2 or 3 , geniculate towards the tip and have many scars; they are medium reddish brown to black brown in colour (Fig. 7, A- $\mathrm{C}$ ). The conidia are light yellowish brown, and cylindrical (Fig. 7, D, E). The size of conidia (about 100) is (45) 95.5 (140) $\mu$ long, (15) 18.6 (25) $\mu$ wide at the widest point, (8) 13.8 (22) $\mu$ at the narrowest point, (2) 5.6 (9) -septa (Fig. 3, 5) (cf. Dreahsler 1923, Ammon 1963, Frauenstein 1968).

Of all the seed lots of $L$. multiflorum examined (15 lots) $73 \%$ were infected by Helminthosporium-species (H. siccans, $H$. dictyoides f. sp. perenne, $H$. catenarium). This corresponds to $9 \%$ (range $0-34 \%$ ) of all the seeds examined. The most common species was $H$. siccans. The fungus was also common on seeds of L. perenne (cf. p 11).
In inoculation tests (Table 2) in which different grass species were inoculated on potato dextrose agar (a few field isolates from seeds and leaves of $L$. perenne, Valinge, as well as that of Festuca pratensis in Peipohja), abundant conidia appeared on Bromus inermis, Dactylis glomerata (Tammisto), L. multiflorum and $L$. perenne, moderate conidia on Festuca pratensis, as well as infrequent conidia on F. rubra, and Phleum pratense. This result is confirmed by Ammon's (1963) observations in her inoculation tests. It differs from the studies of Shoemaker (1962) as well as those of IвrAhim and Threlfall (1966).

$H$. siccans was the seed-borne fungus generally found on the seedlings of Lolium multiflorum and $L$. perenne. This partially explains the abundance of this fungus in samples gathered from nature, although the cultivation of Lolium-species in Finland is insignificant (PAATELA 1953) and their native accurrence is only accidental (HuLtén 1950).

The colony (Fig. 10, H-I), grows rapidly, forming dark, brownish-grey to dark grey, low, dense mycelium. A light grey aerial mycelium later develops over the slant.

Material examined

Plants

On Festuca pratensis:

U: Helsinki 24. IX. 1966 (1 specimen); V: Mie toinen 5. VI. 1969 (1 specimen); St: Peipohja 31. VIII. 1970 (1 specimen); (HPP).

\section{On Lolium multiflorum:}

U: Helsinki (6 specimens); InL: Inari (1 specimen); 1966-70; (HPP).

On Lolium perenne: (of. p. )

Seeds (Numbers cited are SSTS).

On Lolium multiflorum:

Leda 1967 (Commercial seed), 32471, 1968 from Denmark; E. F. 486 Dasas 28056, 1968 from Denmark; Barmultra 20708, 1968 from the Netherlands; Tur 27916, 1968 from Poland; Wiloski 27130, 1969 from Poland.

\section{On Lolium perenne:}

Valinge U: Viik 1967; 6232, 1968, Finnish; Terpas 26417, 1968 from Denmark (SSTS); 12375, 1968 from Denmark; Pajbjerg Senta 20801, 1968 from Poland. 
On Dactylis glomerata:

Tammisto 12369, 1969 from Denmark (SSTS).

Drechslera dactylidis Shoemaker

Canad. J. Bot. 40: 820, 1962.

Perfect stage: Pryrenophora dactylidis Ammon, Phytopath. Zeitsch. 47: 256, 1963. Syn. Pleospora phaeocomes Graham, Phytopathol. 45: 633, 1955. The fungus has been recorded on Dactylis glomerata in the USA (GraHAM 1955, Shoemaker 1962) and in Switzerland (AMmon 1963). In Ammon's inoculation tests typical disease symptoms also appeared e.g. Bromus inermis, Festuca pratensis and Lolium multiflorum.

In this study $D$. dactylidis was found only on the seed. Of all the seed lots of Dactylis glomerata examined (c. 30 lots), about $10 \%$ were (only two lots) infected by this fungus. Conidiophores grow singly, geniculate towards the tip and have occasional scars (Fig. $7 \mathrm{~F}$, G, I); they are light yellowish brown to dark yellowish brown in colour and arise from ascocarps or from leaves. Conidia are light yellow - light yellowish brown to dark yellowish brown. The basal cell is often ligher and narrower than the others; the conidia is often widest at the second or third cells (Fig. $7 \mathrm{H}, \mathrm{J}$ ). The size of conidia (on the seeds) (about 50) is (26) 40.4 (50.5) $\mu$ long, (9) 11.3 (12.6) $\mu$ wide at the widest point, (7) 8.3 (10) $\mu$ wide at the narrowest point, 5.0 (4-6)-septa (Fig. 3, 4). In the present study the size of the spores was smaller than in Shoemaker's (1962) and Ammon's (1963) material. The size of conidia (on the seedling of Dactylis glomerata in the inoculation tests, grown in the incubator) (about 50 conidia) was (84) 144.8 (351) $\mu$ long, (14) 18.1 (22) $\mu$ wide at the widest point, (8) 12.2 (15) $\mu$ wide at the narrowest point, (7) 8.4 (12)-septa (Fig. 3, 4).

In inoculation tests on various grass species (Table 2) inoculated with conidia of $D$. dactylidis produced on potato dextrose agar (an isolate from seeds of Dactylis glomerata TSTO 6075, 1969), abundant conidia appeared on Bromus inermis, Dactylis glomerata, Festuca pratensis, Lolium multiflorum and $L$. perenne as well as moderata conidia on Poa pratensis. This result is confirmed by Ammon's (1963) observations in her inoculation tests. It differs from the studies of Ibrahim and Threlfall (1966).
The colony (Fig. $11 \mathrm{E}$ ) grows rapidly, forming light grey - medium grey, moderately tall, aerial mycelium. Protothecia form rarely. The fungus is long-lived in culture.

Material examined

Seeds (Numbers cited are SSTS)

On Dactylis glomerata:

Fala 26870, 1968 from Poland: TSTO 6075, Finnish.

Helminthosporium vagans Drechsler J. Agric. Res. 24: 688, 1923. Syn. H. poae Baudyš Lotos 64: 81, 1916; Drechslera vagans Shoemaker Canad. J. Bot. 37: 881, 11959; D. poae Shoemaker Canad. J. Bot. 40: 827, 1962. The fungus is a common parasite on many Poa-species, particularly on Poa pratensis e.g. in the USA (Drechsler 1923, 1930, Sprague 1950, Halisky \& Funk 1966), and in Canada (Shoemaker 1962). In Wales the fungus was recorded for the first time in 1938 (SAMpson and Western 1940) in Scotland in 1941 (Dennis \& Foister 1941-42), in Germany in 1941 (MÜHLE 1953, FraUENSTEIN 1968), in Switzerland (Salzmann 1960, Ammon 1963), and in Denmark (SMEDEg̊RdPetersen 1970).

In inoculation tests on various grass seedlings inoculated with conidia of $H$. vagans, disease symptoms appeared on Poa pratensis as well as on the leaves of Bromus inermis, Dactylis glomerata, Festuca pratensis and Lolium perenne (Амmon 1963).

During the present study $H$. vagans was found on Poa pratensis. Of all the material (c. 230 samples) collected from different localities (Helsinki, Hyrylä, Hämeenlinna, Peipohja, Inari) (Fig. 1) about $30 \%$ was infected by the fungus. Of all the seed lots of $P$. pratensis examined (11 lots, from the State Seed Testing Station), about $36 \%$ were infected by the fungus. This corresponds to only $0.5 \%$ of the seeds examined. Disease symptoms and spores of the fungus were found on the leaves from early spring (April) till late autumn (November). The fungus caused well-defined, oval leaf-spots with a chocolate brown to violet brown margin and white to sand-coloured centre (Fig. $2 \mathrm{M}$ ). The lesions were often framed with a circle, mostly sand-coloured to greyish orange in colour. The size of lesions (500) was (1.0) 3.8 (22) mm long. (0.5) $0.9 \quad(4.0) \quad \mathrm{mm}$ 
wide. Cionidiophores emerged from the epidermal cells; on occasion from little black sclerotia on the leaves of the host, singly or in small groups, that are yellowish brown in colour (Fig. 6, O-P). Conidia are dark brown - dark olive brown, when young they are yellowish grey, subcylindrical, tapering toward the hemispherical ends (Fig. 6, L$\mathrm{N}, \mathrm{Q}$ ). The size of conidia (about 100) is (30) 86-109 (166) $\mu$ long, (15) 19.5-21.4 (28) $\mu$ wide, (3) 7.5-9.1 (11)-septa (Fig. 3, 6) (cf. Shoemaker 1962, SMedegårdPetersen 1970).

In inoculation tests (Table 2) in which different grass species were inoculated with conidia of $H$. vagans that were produced on potato-dextrose agar (an isolate from seeds of Poa pratensis, Nike 9138, 1969 from Denmark), abundant conidia appeared on Bromus inermis, Dactylis glomerata (Esko), Lolium multiflorum, L. perenne, Phleum pratense (Tarmo) and Poa pratensis. When an isolate from a field at Viik was used, scarce conidia appeared on Alopecurus pratensis, Bromus inermis, Festuca pratensis, Lolium perenne and Poa pratensis (cf. Ammon 1963).

$H$. vagans was the seed-borne fungus found on the seedlings of Poa pratensis.

The colony (Fig. 11, G) grows very slowly, forming dark, brown - black slants with irregular margins. The fungus penetrates into the surface of the agar.

Material examined

Plants.

\section{On Poa pratensis:}

U: Helsinki (53 specimens), Hyrylä (6 specimens); EH: Hämeenlinna (3 specimens); St: Peipohja (1 specimen); InL: Inari (3 specimens); in 1966-70 (HPP).

\section{On Poa annua:}

EH: Iitti (1 specimen) (HPP).

Seeds (Number cited are SSTS)

On Poa pratensis:

Golf 31066, 1968 from Sweden; Soma Hundbolle 33586, 1968 from Denmark; Nike 9138, 2221, 1969, from Denmark.

Helminthosporium tritici-repentis Diedicke Centralbl. Bakt. Paras. Infekt. Krankh. Abt. 2, 11: 56, 1904. Syn. Drechslera triticirepentis Shoemaker Canad. J. Bot. 37: 880,
1959. Perfect stage: Pyrenophora triticirepentis (Died.) Drecshler J. Agric. Res. 24: 667, 1923. Syn. cf. Shoemaker 1962: 831. The species has been reported to be common on many grass species (Sprague 1950, ShoeMAKer 1962) e.g. on Agropyron repens (L.) PB in the USA (Dreahsler 1923, Sprague 1950), in Canada (Shoemaker 1962), in Germany (Diedicke 1902, 1904, Noack 1905), in Britain (Dennis \& W AKEFIELd 1946), in Denmark (ANDERSEN 1955) and to Triticum durum Desf. in Italy (Del Vescovo 1962). In inoculation tests, with an isolate from Triticum aestivum, symptoms of diseases appeared on Agropyron repens and Triticum vulgare $\mathrm{L}$.

In the present study $H$. tritici-repentis was found on Agropyron repens from certain localities ranging from Helsinki to Inari (Fig. 1). $50 \%$ of the material studied (c. 35 samples) was infected by the fungus. According to the author's observations the disease is common in Finland. The fungus produced abundant delicate, necrotic blackbrown spots and streaks (Fig. 2, N-O) or greater lighter (umbra - greyish brown) lesions on the leaves and dead tips of blades. The lesions (170) were (0.5) 2.2 (16) $\mathrm{mm}$ long, (0.5) 0.8 (2.5) $\mathrm{mm}$ wide.

Conidicphores usually assume a simple, individual, unbranched form, they are long and dark olivaceous in colour (Fig. $8 \mathrm{E}, \mathrm{I}$ ). Conidia are subhyaline, straight - cylindrical basal spore segment tapering to a rounded cone shape (Fig. 8 D, F, G) (cf. Drechsler 1923, Dennis \& Wakefield 1946, Shoemaker 1962, Rapilly 1964). Conidia (about 100) are (44) 98 (168) $\mu$ long, (12) 15. 5 (22) $\mu$ wide at the widest point, (8) 11.7 (20) $\mu$ at the narrowest point, (3) 6.8 (11)-septa (Fig. 3, 10) (cf. Drechler 1923, Ammon 1963).

In inoculation tests on various cereals and grass species (Table 2) inoculated with conidia of $H$. tritici-repentis produced on potatodextrose agar (many isolates from leaves of Agropyron repens), not a single species was infected.

The colony (Fig. $11 \mathrm{~F}$ ) grows slovoly forming a dense, white to yellowish grey mycelium. Protothecia often form. The fungus is longlived in culture (cf. Shoemaker 1962).

The mature ascocarps of Pyrenophora tritici-repentis were found in early spring (May -June), immature ascocarps were found in 


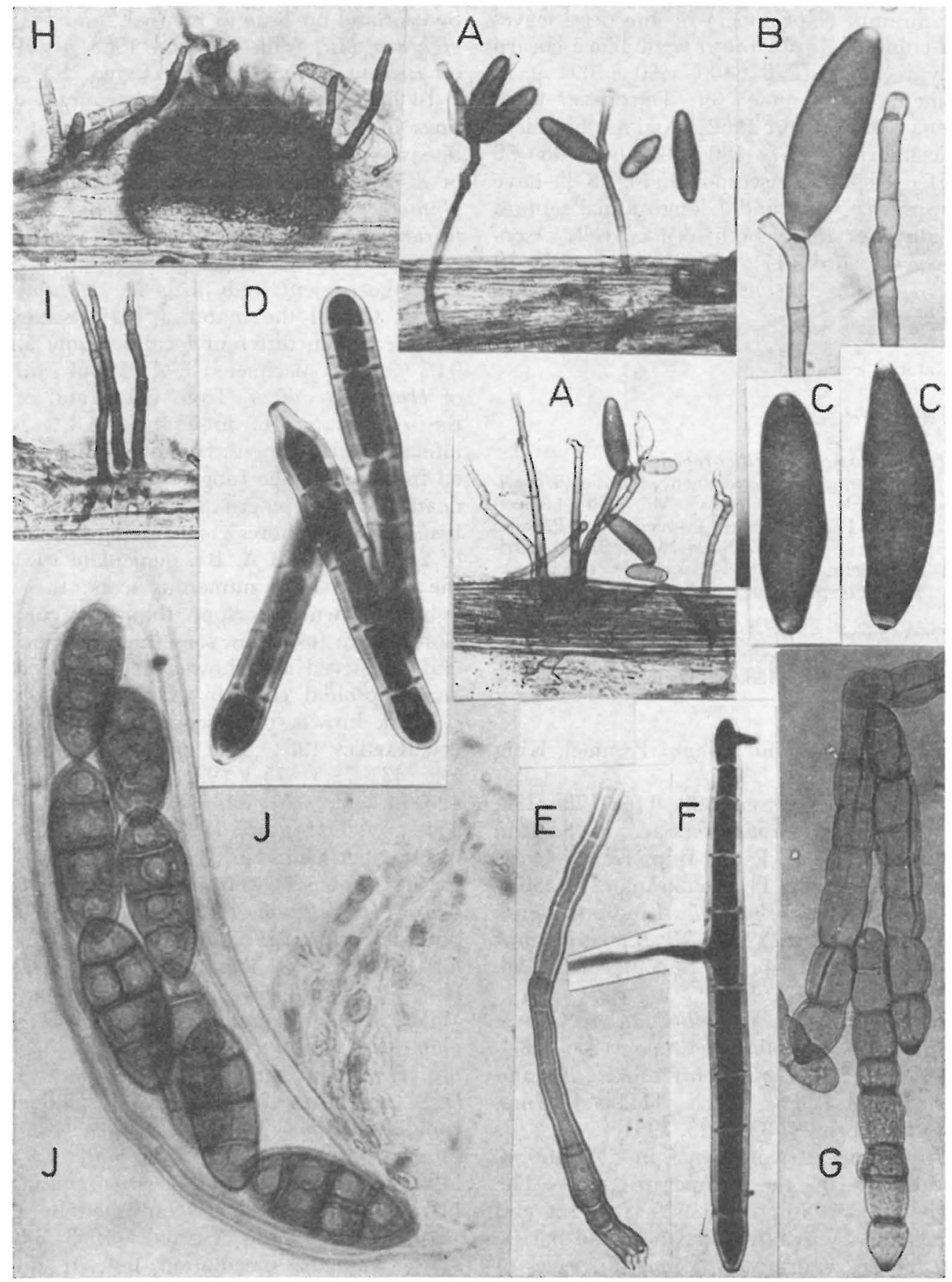

Fig. 8. Conidia and conidiophores of Helminthosporium sativum, A: on Festuca pratensis, B: on Bromus inermis, C: on Phleum pratense, those of $H$. tritici-repentis, D-I on Agropyron repens. Ascus and ascuspores of Pyrenophora tritici-repentis, J: on A. repens. A-B: on seeds, G-J: on leaves from fields. A: 'Tammisto' 37682, 1963, from the USA, B: 'Jo 266' Jokioinen, 1968, C: Helsinki 8. VI. 1970, D: Mikkeli 28. VI. 1968, E: Inari 13. VII. 1969, F: Ikaalinen 17. VIII. 1970, G-I: Pälkäne 17. VIII. 1970, J: Hämeenlinna 3. XI. 1967 (in laboratory $+10^{\circ} \mathrm{C}$ to 16 . II. 1968). A, $\mathrm{H}-\mathrm{I} \times 150, \mathrm{~B}-\mathrm{G} \times 40.0, \mathrm{~J} \times 600$. 
late autumn (November) on the dead leaves and culms of Agropyron repens. The ascocarp body is black (270) 400-450 (700) $\mu$ in diameter with setae (cf. Drechler 1923, Rapilly \& Ponghet 1962). Asci are bitunicata, cylindrical (167) 180 (200) $\mu \times(36) 50$ (60) $\mu$ 8-spored. Ascospores (Fig. $8 \mathrm{~J}$ ) have 3 transverse septa and 1 longitudinal septum in either, or rarely both, central cells. Ascospores measure (44) 50 (61) $\mu \times$ (12) 19 (24) $\mu$ (cf. Drechsler 1923, Shofmaker 1962).

Material examined

On Agropyron repens:

Helminthosporium tritici-repentis

U: Kirkkonummi (1 specimen), Siuntio (1 specimen), Helsinki (6 specimens), Mäntsälä (1 specimen); EH: Hämeenlinna (4 specimens), Pällkäne (1 specimen); PH: Ikaalinen (1 specimen), Orivesi ( 1 specimen); ES: Mikkeli (1 specimen); InL: Inari (1 specimen); in 1967-70; (HPP).

Pyrenophora tritici-repentis

U: Helsinki (2 specimens); EH: Hämeenlinna (1 specimen); ES: Mikkeli (1 specimen); in 1967 -68; (HPP).

Helminthosporium sativum Pammel, King and Bakke

Iowa Agric. Exp. Sta. Bull. 116: 178-190, 1910. Syn. H. sorokinianum Sacc. (in Sorokin in Trudy Obshch. Estest Imp. Kazan Univ. Abstr. in Zeitschr. Pflanzenkrankh. 1: 236239,$1891 ; H$. acrothecioides Lindfors Svensk Bot. Tidskr. 12: 227, 1918; Bipolaris sorokiniana (Sacc. in Sorok.) Shoemaker Canad. J. Bot. 37: 884, 1959.

Perfect Stage: Cocliobolus sativus (Ito et Kurib.) Drechsler Phytopathology 24: 973983, 1934. Syn. Ophiobolus sativus Ito and Kuribayashi J. Fac. Agric. Hokkaido Imp. Univ. Sapporo 29: 85-125, 1931.

$H$. sativum is world-wide in distribution, particularly in the temperate zone. The species is most important as a root rot and kernel smudge or blight of wheat and barley. It has been reported on dozens of species of grasses in the USA (Sprague 1950, Nelson \& KuINE 1962), causing e.g. severe seedling blight (ANDREWS 1953). The fungus occurs in Europe, e.g. in Denmark on plants of Agropyron repens, Festuca pratensis, Lolium multiflorum and $L$. perenne, and on seeds of Dactylis glomerata, $F$. pratensis, $F$. rubra and L. multiflorum (ANDERSEN 1953, 1955), in
Switzerland on Bromus mollis L. and Festuca gigantea (L.) Vill. (Амmon 1963), in Italy on Lolium perenne (Del Vescovo 1962).

In inoculation tests on various grass seedlings inoculated with conidia of $H$. sativum disease symptoms appeared e.g. on the leaves of Agrostis alba L., Bromus inermis, Dactylis glomerata, Festuca pratensis, Lolium multiflorum, Phleum pratense and Poa pratensis (Ammon 1963; cf. Sprague 1950: 378).

In the present study little $H$. sativum was found. Of all the material (3770 samples) collected from different localities only about $0.05 \%$ (two specimens) besides four samples of Hordeum vulgare from fields, and of all the seedlots (c. 160 lots) about $3.8 \%$ were infected by the fungus. In the material collected from nature the fungus emerged from the death-brown epidermal cells of the host tissue. Conidiophores grow singly or in groups of 2 or 3 (Fig. $8 \mathrm{~A}, \mathrm{~B}$ ), geniculate towards the tip and have numerous scars; they are lighter brown in colour than the conidia. Conidia are fusiforms, sometimes not equilateral or curved and show a hemispherical or hemiellipsoidal contour (Fig. $8 \mathrm{C}$ ); brown - dark brown, microscope black in colour (cf. Rapilly 1964). The conidia (about 120) are (43) 72.5-75.3 (92) $\mu$ long, (16) 20.3 (28) $\mu$ wide, (5) 7.1-7.6 (11)-septa (Fig. 3, 8) (cf. Dreahsler 1923, Andersen 1955).

In experiments in which different grass species (Table 2) were inoculated with conidia of $H$. sativum, that were produced on potato-dextrose agar (an isolate from seeds of Festuca pratensis, Tammisto 7803, 1969, Finland and from leaves of Agrostis tenuis at Viik), abundant conidia appeared on Dactylis glomerata, Lolium multiflorum, L. perenne, Hordeum vulgare L., Secale cereale L. and Triticum aestivum L., moderate conidia on Bromus inermis, Festuca pratensis, Phleum pratense and Poa pratensis and infrequent conidia on Agrestis tenuis and F. rubra. This result is confirmed by PuTTERILL's (1954) and Ammon's (1963) observations in her inoculation test. It differs substantially from the studies of IBRAHIM and Threfall (1966). According to them only Hordeum vulgare was infected.

$H$. sativum was the seed-borne fungus found on the seedlings of, at least, Bromus inermis.

The colony (Fig. 11, H-I) grows rapidly or slowly, forming a velvety layer of grey to 
brown-black mycelium. Conidiophores and multiform conidia develop in masses. The fungus is longlived in culture (cf. Drechsler 1923, Malone \& Muskett 1964).

No perfect stage was found.

Material examined

Plants

On Agrostis tenuis:

U: Helsinki (Viik) 7. VIII. 1970; (HPP).

On Bromus inermis:

U: Helsinki (Viik) 20. X. 1970; (HPP).

On Phleum pratense:

U: Helsinki (Viik) 8. VI. 1970; (HPP).

On Hordeum vulgare:

U: Mäntsälä 9. IX. 1970; EH: Hollola 23. VIII. 1970; PH: Kangasala 17. VIII. 1970, Orivesi 17. VIII. 1970; (HPP).

Seeds (Numbers cited are SSTS)

On Bromus inermis:

Jo 266, EH: Jokioinen 1968; S-1389, 1968 from Canada.

On Festuca pratensis:

Paavo, EH: Jokioinen 1967; Tammisto 7803, 1969, Finnish; Tammisto 37682, from the USA, Shafter, 1963.

On Lolium perenne:

Terpas 26417, 1968, from Denmark.

On Phleum pratense:

Tarmo 9944, 1970, Finnish.

On Secale cereale:

Ensi, Viik, 1969.

On Triticum aestivum:

U: Helsinki, Viik, Elo, 1969.

Helminthosporium biforme Mason and Hughes

Chesters in an appendix Trans. Brit. Mycol. Soc. 30: 113-117, 1948. Syn. cf. Chesters (1948: 114); H. biseptatum Sacc. and Roum. (Ibrahim and Threlfall 1966: 369). The species was recorded during the testing of the Northern Irish seed Avena sativa L. for health (Malone \& MusketT 1964) and was also observed on Apium graveolens L. seed (Ibrahim \& Threlfall 1966).

In the present study little $H$. biforme was found. Of all the material ( 3770 samples) collected from different localities, only about $0.05 \%$ (two specimens) and of all the seed lots (c. 160 lots), about $5.6 \%$ suffered infection by the fungus. In the material collected from nature the fungus emerged from the death-brown epidermal cells of the host tissue. The fungus produces two kinds of conidiophores. Macronematous conidiophores arise from sclerotinia-like bodies, are dark brown, and taper slighty towards the geniculate tip; they are up to $300 \mu$ long, and (4.5) - 5.0-(7) $\mu$ wide (Fig. $9 \mathrm{G}, \mathrm{I}$ ). Micronematous conidiophores are formed at the widening and darkening of the ends of the hyphae, which become geniculate (Fig. $9 \mathrm{E}, \mathrm{G}, \mathrm{J}$ ). The conidia are the same in both cases. They are generally obovate, sometimes elliptical, pale brown - yellowish brown exsept for the lighter - coloured basal cell, and the dark brown scar at the narrower end (Fig. 9, E-F, H). The size of conidia (about 50) (18) 26.9 (36) $\mu$ long, (8) 12.5 (20) $\mu$ wide at the widest point, (5) 6.4 (9) $\mu$ at the narrowest point, (3) 3.7 (5)-septa (Fig. 3, 9) (cf. Chester 1948, Malone \& Muskett 1964).

In experiments in which different grass species (Table 2) were inoculated with conidia of $H$. biforme, that were produced on potato dextrose agar (an isolate from seed of Festuca ovina 13412, 1969, foreign), abundant conidia appeared on Bromus inermis, Festuca pratensis (Leto), and Lotium multiflorum, moderate conidia on Festuca rubra and Poa pratensis and infrequent conidia on Dactylis glomerata and Phleum pratense. This result differs substantially from the studies of Ibrahim and Threlfall (1966), who found only Festuca pratensis infected.

The colony (Fig. 11, J-K) grows rapidly, forming uniform, dark grey — dark brownish grey - brownish black, low, dense mycelium. The margin is light grey. Conidiophores and conidia develop abundantly. The fungus is long-lived in culture.

Material examined

Plants

On Agrostis stolonifera:

U: Helsinki, Viik, 8. VI. 1970: (HPP).

On Phleum pratense:

U: Helsinki, Viik, 22. VI. 1970; (HPP).

Seeds (Numbers cited are SSTS).

On Agrostis tenuis:

Kito 27917, 1967 from Poland.

On Dactylis glomerata:

Tammisto, from the USA, Masshardy, 1963; (HPP). 


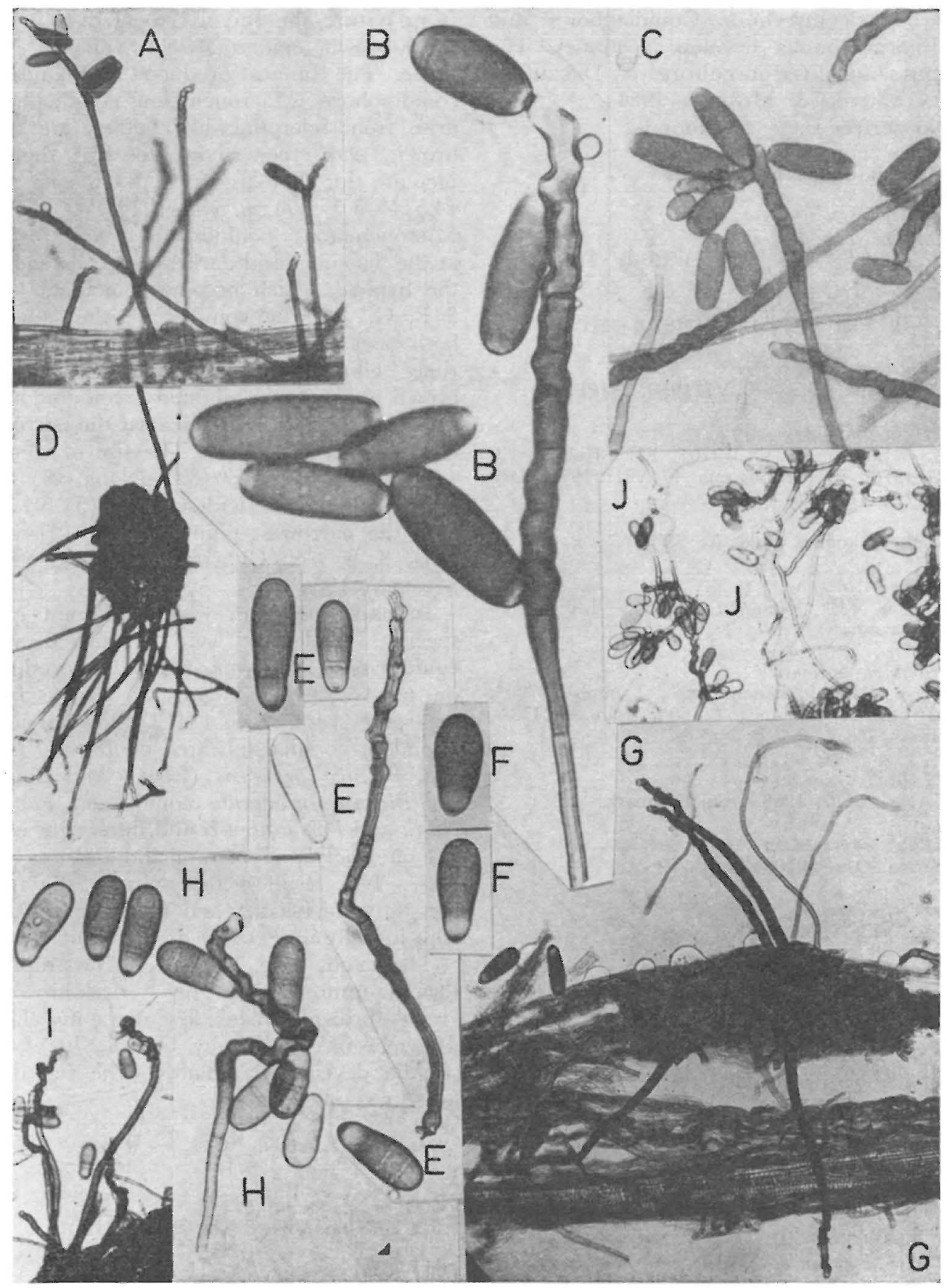

Fig. 9. Conidia and conidiophores of Helminthosporium triseptatum, A: on Phleum pratense, B-C: on Potato-dextrose agar, those of $H$. biforme, D-F: on Fectuca ovina, G: on $F$, rubra var. fallax, H-J: on Dactylis glomerata, A: on leaves from fielld, D-J: on seeds. A: Helsinki 12. VI. 1968, D-E: 13412, 1969, Foreign, F: 9157, 1969 from Germany, H: 14324, 1969, from the Netherlands, $\mathrm{H}-\mathrm{J}$ : isolated from seed produced in the USA (Masshardy in 1963). A, G, I, J $\times 150, \mathrm{~B} \times 1000$, $\mathrm{D} \times 75, \mathrm{C}, \mathrm{E}, \mathrm{F}, \mathrm{H} \times 400$. 
On Festuca ovina:

9157, 1969, from Germany; 13412, 1969, Foreign.

On Festuca rubra:

Dasas 24897-98, 1968, from Denmark: Rubina Roskilde 21481, 1968, from Denmark; Highlite, GVE 627, from the Netherlands.

On Festuca rubra var. fallax:

14324, 1969, from the Netherlands.

On Lolium multiłlorum:

Leda, commercial seed, 1968, from Denmark.

On Phleum pratense:

Solf 26885, 1968, from Sweden.

Helminthosporium triseptatum Drechsler J. Agric. Res. 24: 686, 1923. The species has been recorded to occur on Holcus lanatus L. in the USA (Dreahsler 1923, Diakson 1947, Sprague 1950), in Canada (Shoemaker 1962) and in Britain (DenNis \& Wakefield 1946, Iвrahim \& Threlfall 1966). The fungus reportedly also infects Agrostis-species (Dickson 1947, LutTrell 1951, Salzmann 1959) e.g. A. alba L., $A$. exarata Trin. (Sprague 1950), A. gigantea Roth. (Dickson 1947) and $A$. stolonifera L. (IвRAHIm \& Threlfall 1966), Dactylis glomerata (Dickson 1947, Sprague 1950) and Phleum pratense (Diakson 1947, Ibrahim \& Threlfall 1966), Poa pratensis (BEAn 1964), as well as Sorghum halopense L. in Italy (Del Vescovo 1962).

In the present study little $H$. triseptatum was found. Of all the material (3770 samples) collected from different localities, only about $0.03 \%$ (one specimen), and of all the seedlots (c. 160 lots) about $3.1 \%$, suffered infection by the fungus. The last mentioned seed lots were prof. Otto Valle's experiments, which were produced in the USA (cf. p. 3). Conidiophores grow on withering leaves, singly or in pairs, geniculate towards the tip and have numerous scars (Fig. 9, A-C); they are dark olivaceous to black brown in colour. On the upper part of conidiophores thickenings occur (Fig. 9 B) (cf. Drechsler 1923). Conidia are dark olivaceous to black brown; ellipsoidal or short cylindrical, regularly 2- to 3-septate (Fig. $9 \mathrm{~B}$ ). The conidia (about 100) are (22) 26.8-34.0 (39) $\mu$ long, (8) 9.7-11.1 (14) $\mu$ wide, 3-septa (Fig. 3, 10). In this study conidia were smaller than those examined by DrechsLeR (1923).

In experiments in which different cereals and grass species (Table 2) were inoculated with conidia of $H$. triseptatum that were produced on potato dextrose agar (an isolate from leaves of Phleum pratense at Viik), abundant conidia appeared on Bromus inermis, Lolium multiflorum, $L$. perenne and Triticum aestivum; all the other species were also infected. This result is confirmed by Sprague's (1950) view that the fungus is saprophytic or weakly parasitic; however, the result differs essentially from the studies of Ibrahim and Threlfall (1966) who found only Phleum pratense infected.

The colonies (Fig. 11 L) grow rapidly, first forming a light olivaceous, then dark black-brown myselium. Conidiophores and conidia develop in masses. The fungus is long-lived (at least two years) in culture. Protothecia were not produced.

No perfect stage was found.

Material examined

Plants

On Phleum pratense:

U: Helsinki (Viik), 12. VI. 1968.

Seeds

On Dactylis glomerata:

Tammisto 387316, produced in the USA, Tehachapi 19:65.

\section{On Festuca pratensis:}

Tammisto, Tikkurila 1960, 37672, produced in the USA, Tehachapi 1963; 39683, produced in the USA, Tehachapi 1967; 38718 produced in the USA, Shafter 1965.

\section{Discussion}

In the present study samples from localities throughout the country, from Ahvenanmaa to Lapland, were examined. The majority of the localities were Experiment Stations of the Agricultural Research Centre. Thus, the experiments were fairly uniform. The greater part of the samples was obtained from Viik (Helsinki). The leys studied were composed principally of one grass-species. In this respect they differed essentially from the typical Finnish ley. In Finland red clover-timothy leys are the most common type of cultivated leys (Raininko 1968). It is generally known that a growing unit composed of only one plant species is more susceptible to diseases than a heterogenous growing unit. On the other hand in Finland wild grass is common 
throughout the country (HULTÉn 1950, PAATELA 1953). This makes the spread of grass diseases possible. Studies carried out by the author indicate that this notion is correct, at least as far as the species Mastigosporium (Mäkel̈̈ 1970) and Helminthosporium are concerned. Many species of Helminthosporium are known to be seed-borne fungi (Mühle 1953, Andersen 1955, 1959, SahaRIF 1961). This exlains e.g. that Helminthosporium f. sp. perenne was found on Lolium perenne in Muddusniemi (Inari) although neither $L$. perenne nor other hosts of the fungus grow there in nature (HultéN 1950).

In most species of Helminthosporium viable conidia were found immediately after the snow had melted or shortly thereafter. Sclerotial bodies were also found in certain Helminthosporium-species ( $H$. dictyoides $\mathrm{f}$. sp. perenne, $H$. vagans); the perfect stage was found only in one species ( $H$. triticirepentis). The long Finnish winter, the length of the thermal winter $\left(0^{\circ}-0^{\circ} \mathrm{C}\right)$ varying from 100 to 205 days (KolKKI 1966), did not prevent most Helminthosporium-species from over-wintering at the conidia-stage (cf. Mühle 1953). In this contury the snow cover plays an important part in affecting the soil temperature as well as the dormant period of plants (YLIMÄKr 1962). The disease symptoms and spores of the fungus were found generally during the period between early spring (March) and late autumn (November). This is true in spite of the fact that the optimum temperature for many graminicolous species of Helminthosporium is from $10^{\circ}$ to $22^{\circ} \mathrm{C}$ (LeAci 1967). The amount of conidia was most abundant in mid and late summer. However, great variation was observed between the species of girasses, times of collection and the different localities. It was most abundant during the moist periods (cf. Dreghsler 1930, Sampson \& Western 1940, Mühle 1953, Halisky \& Funk 1966, FrauenSTEIN 1968).

In the present study a close affinity was confirmed in the occurrence of Helminthosporium-species between the researched plant samples and seed lots of the same grass-species. Thus Helminthosporium-species occurred commonly on Phleum-pratense, Festuca pratensis, Lolium perenne and L. multiflorum in both plant and seed samples. On the contrary Helminthosporium occurred scant- ily on Dactylis glomerata and Alopecurus pratensis, in both plant and seed samples.

The new foreign Helminthosporium-species which are carried by the seed are significant only when they are able to adapt to these new conditions. For example the seeds of Finnish-originated Phleum pratense, Festuca pratensis and Dactylis glomerata were produced in the USA. However, only one Helminthosporium-species has been confirmed to be transported with them; H. triseptatum was found only once, in nearly negligible quanity, at Viik (Helsinki).

Many Helminthosporium-species are cosmopolitan. This concept is also confirmed by the results of this study.

\section{Summary}

Helminthosporium phlei (Graham) Scharif was found frequently on Phleum pratense L. in leys throughout the country. The fungus was common also on the seed of timothy produced in Finland.

Helminthosporium dictyoides Drechs. f. sp. dictyoides Braverman \& Graham was found very commonly and in adundance on Festuca pratensis Huds. in leys throughout the country. The fungus was very common also on the seed of medow fescues produced in Finland. The fungus was also found on F. rubra L., Dactylis glomerata L. and Alopecurus pratensis L. in leys, though less commonly and less significantly than on $F$. pratensis.

Helminthosporium dictyoides Drechs. f. sp. perenne Braverman \& Graham was found common on Lolium perenne L. in some localities. The fungus was also found on the seed of perennial rye-grass produced both in Finland and in foreign countries.

Helminthosporium siccans Drechs. was found to be fairly common on Lolium multiflorum Lam. and $L$. perenne $\mathrm{L}$. on leys in some localities. The fungus was also found to be very common on seed of Lolium-species produced in Finland and Denmark, as well as on seed of Dactylis glomerata produced in Denmark, $H$. siccans was also found on Festuca pratensis in leys in some localities.

Helminthosporium vagans Drechs. was found to be moderately common on Poa pratensis $\mathrm{L}$. on leys in localities from Helsinki to Inari. One occurrence was recorded on Poa annua L. at Iitti. The fungus was also 
found to be fairly common on seed of $P$. pratensis produced in foreign countries.

Helminthosporium sativum Pammel, King \& Bakke was found to be uncommon and infrequent on Phleum pratense L., on $\mathrm{Ag}$ rostis tenuis Sibth., and on Hordeum vulgare L. in fields in certain localities in southern Finland. The fungus was found also on seed of Bromus inermis Leyss., Festuca pratensis Huds., Lolium perenne L., Phleum pratense L., Secale cereale L., and Triticum aestivum L. produced both in Finland and in foreign countries.

Helminthosporium biforme Mason \& Hughes was found to be very uncommon and infrequent on Agrostis stolonifera L. and on Phleum pratense in one ley at Viik (Helsinki). The fungus was found more frequently on seed of Agrostis tenuis, Dactylis glomerata, Festuca ovina L., F. rubra L., F. rubra var. fallax, Phleum pratense and Lolium perenne produced in foreign countries.

Helminthosporium triseptatum Drechs. was found in very small quantities on Phleum pratense on only one ley at Viik (Helsinki). The fungus was also found to be very uncommon on seed of D'actylis glomerata, and Festuca pratensis produced in the USA.
Helminthosporium tritici-repentis Diedicke was found very common on Agropyron repens (L.) PB. on the borders of fields is many localities throughout the country. Pyrenophora triticirepentis (Died.) Drechs., the perfect stage of the fungus, was found in certain localities in southern Finland (Hämeenlinna, Mikkeli).

Small quantities of Drechslera dactylidis Shoemaker were found only on seed of Dactylis glomerata produced both in Finland and in Poland.

Acknowledgements. - I express my sincere thanks to Mrs. Eila Metsäpelto, M. Sc., who previously examined a part of the materials from Viik in 1966 - 68 in her pro gradu study at Helsinki University. I am thanikful to Mrs. Aino Hanhilahti, Agr., Miss Ritva Prokkkola, M. Sc., Mr. Heikki Jouppila, M. Sc., and also to many other persons for their technical assistance, e.g. in collecting and analyzing plant specimens and measuring spores. I am also thankful to Mr. Pentti Heinänen for photographing my microsicopic slides, as well as to Mr. Jorma Kuntto, M. Sic. for the organization of my field experiments. My thanks also to the Experiment Stations of the Agricultural Research Centre, the Plant Breeding Institute of Hankkija and the State Seed Testing Station as well as to the late Prof. Otto Valle for research materials. I am grateful to the University of Helsinki and to my late husband Dr. Aarne Mäkelä for their finncial assistance.

\section{REFERENCES}

Ainsworth, G. C. 1961: Ainsworth \& Bisby's Dictionary of the fungi. - 547 pp. Kew Surrey.

Ammon, H. V. 1963: Uber einige Arten aus den Gattungen Pyrenophora Fries und Cochliobolus Drechsler mit Helminthosporium als Nebenfruchtform. - Phytopathol. Zeitsch. 47: $244-300$.

Andersen, H. H. 1955: Sipecies of Helminthosporium on cereals and grasses in Denmark. Friesia 5: 80-89.

- 1959: Helminthosporium catenarium Drechs. på graesser i Danmark. - Tidskr. Planteavdeln. 63: 710-736.

Andrews, E. A. 1953: Seedling blights and root rat of forage grasses. - Diss. Abstr. 13: 962

Baudyš, E. 1916: Ein Beitrag zur Kenntnis der Mikromyceten in Böhmen. - Lotos 64: $80-90$.

Bean, G. A. 1964: Prevalence of Curvularia pallescens and Helminthosporium spp. pathogenic on bluegrass in the Washington, D. C., area. Fifty-sixth Annual Meeting of the American Phytopathological Society. Abs. in Phytopathol. 54: 886-913.

Bravermann, S. W. \& Graham, J. H. 1960: Helminthosporium diotyoides and related spe- cies on forage grasses. - Phytopathol. 50: $691-695$.

Brummer, V. 1937: Beobachtungen über die in Finnland auf dem Timothee auftretenden Pilzkrankheiten. - J. Scient. Agric. Soc. Finland 9: 165-180.

Couch, H. B. \& Golf, H. 1957: Chemical control of melting - out of Kentucky Blue-grass. - Plant Dis. Rep. 41: 205-208.

Del Vescovo, M. 1962: Contributo alla conoscenza di alcune »elmintosporiosi» di Graminacee spontanee e collivate nella regione AppuloLucana. - An. Fac. Agrar. Univ. Bari. 16: $137-159$.

Dennis, R. W. G. \& Foister, C. E. 1942: List of diseases of econimic plants recorded in S.cotland. - Trans. Brit. Mycol. Soc. 25: $266-306$.

- \& W AKefield, E. M. 1946: New or Interesting British Fungi. - Ibid. 28: 141-166.

Drakson, J. G. 1947: Diseases of field crops. 429 pp. New York \& London.

Diediake, H. 1902: Ueber den Zusammenhang zwischen Pleospora und HelminthosporiumArten. I. - Centralbi. Bakt. Paras. Infekt. Krankh. Abt. 2, 9: 317-32..

- 1904: Ueber den Zusammenhang zwischen 
Pleospora und Helminthosporium-Arten. II. - Ibid. 11: 52-59.

Dovaston, H. F. 1948: A new species of Pyrenophora from Italian Ray-grass. - Trans. Brit. Mycol. Soc. 31: 249-253.

Drechsler, C. 1923: Some graminicolous species of Helminthosporium. I. - J. Agric. Res. 24: $641-740$.

- 1930: Leaf spot and root rot of Kentucky blue grass caused by Helminthosporium vagans. - J. Agric. Res. 40: 447-456.

Earhart, R. W. 1953: Comparisons of Helminthosporium-species attacking oats in Florida. Phytopathol. 43: 516-518.

ElliotT, E. S. 1962: Disease damage in forage grasses. - Phytopathol. 52: 448-451.

Frauenstein, K. 1968: Beobachitungen zum Auftreten von Blattfleckenkrankheiten an Futtergräsern. - Nachr. Bl. Deutschen Pflanzenschutzd., Berlin N. F. 22: 4-14.

Graham, J. H. 1955: Helminthosporium leaf streak of Timothy. - Phytopathol. 45: 227-228.

Halisky, P. M. \& Funk, C. R. 1966: Environment factors affecting growth and sporulation of Helminthosporium vagans and its pathogenity to Poa pratensis. - Phytopathol. 56: 1294-1296.

Hittonen, I. 1933: Suomen kasvio. - 771 pp. Helsinki.

Hughes, S. J. 1953: Conidiophores, conidia, and classification. - Canad. J. Bot. 31: 577659.

Hultén, E. 1950: Atlas of the distribution of vascular plants in NW Europe. - 512 pp. Stockholm.

Ibrahim, F. M. \& Threlfall, R. J. 1966: The application of numerical taxonomy to some graminicolous species of Helminthosporium. - Proc. R. Soc. London Ser. B. 165: 3.62388.

Iто, S. 1930: On some new ascigerous stages of the species of Helminthosporium parasitic on cereals. - Proc. Imp. Acad. Tokyo, 6: $352-355$.

Ito, S. \& Kuribayashi, K. 1931: The ascigerous forms of some graminicolous species of Helminthosporium in Japan. - J. Fac. Agric. Hokkaido Univ. Sapporo 29: 85-125.

Karsten, P. A. 1884: Fragmente Mycologica XII. - Hedwigia 23: 39-40.

Kenneth, R. 1958: Contribution to the knowledge of the Helminthosporium Flora on Gramineae in Israel. - Bull. Res. Counc. Israel, Sec. D. 6 D: $191-210$.

Kоцккт, O. 1966: Tables and maps of temperature in Finland during 1931-1960. - Suppl. Meteorol. Yearb. Finland 65, 1a: 1-42.

Kornerup, A. \& Wanscher, J. H. 1967: Methuen handibook of colour. - 2nd ed. $243 \mathrm{pp}$. London.

LAtch, G. C. M. 1966: Fungous diseases of Ryegrasses in New Zealand. I. Foliage diseases. - New Zealand J. Agric. Res. 9: 394409 .

Lindfors, T. 1918: Mykologische Notizen. Svensk Bot. Tidskr. 12: 221-227.

LutTrell, E. S. 1951: A key to species of Helminthosporium reported on grasses in the
United States. - U. S. Dept. Agric. Plant Dis. Rep. 201: 59-67.

Luttrell, E. S. 1954: Approaches to the classification of Helminthosporium species. U. S. Dept. Agric. Plant Dis. Rep. Sup. pl. 228: $111-113$.

- 1964: Systematics of Helminthosporium and related genera. - Mycologia 56: 119132.

Mäkelä, K. 1970: The genus Mastigosporium Riess in Finland. - Karstenia 11: 5-22.

Malone, J. P. \& Muskett, A. E. 1964: Seed borne fungi description of 77 fungus species. Proc. Int. Seed Test. Assoc. 29 (2): 179384.

Meehan, F. 1947: A host index to seed-borne species of Helminthosporium and Curvularia on centain grasses. - Proceed. Assoc. Off. Seed Analysits. 1947: 89-92.

Monthly Review of Agrigultural Statistics. August 1969. - Board of Agric. Statist. Off. Helsinki 8: 127-151.

MüHLE, E. 1953: Die Krankheiten und Schädlinge der zur Samengewinnung angebauten Futtergräser. - 167 pp. Leipzig.

Neergaard, P. 1956: 7 Årsberetning verdrørende frøpatologisk kontrol i Juni 1954- 31 Maj 1955. Copenhagen.

Nelson, R. R. \& Kline, D. M. 1962: Introspecific variation in pathogenicity in the genus $\mathrm{Hel}$ minthosporium to gramineous species. Phytopathol. 52: 1045-1049.

Nisikado, Y. 1928: Studies on the Helminthosporium diseases of gramineae in Japan. Spec. Rep. Ohara Inst. Agric. Res. 4: 111 $-162$.

NoAck, F. 1905: Helminthosporium gramineum Rabenh. und Pleospora trichostoma Wint. - Zeitsch. Pflanzenkrankh. 15: 193-205.

PaAtela, J. 1953: Maamme heinänurmien botaanisesta koostumuksesta. Summary. On the botanical composition of the tame hayfield in Finland. - Acta Agralia Fennica 79 (3) : $1-128$.

Pammel, L. H., King, C. M. \& Bakke, A. L. 19.10: Two Barley Blight, with comparison of species of Helminthosporium upon cereals. Iowa Agric. Exper. Stat. Bull. 116: 178190.

Paul, A. R. \& Parbery, D. G. 1968: Pyrenophora dictyoides sp. nov. the perfect state of $\mathrm{Hel}$ minthosporium dictyoides. - Trans. Brit. Mycol. Soc. 51: 707-710.

Putterill, K. M. 1954: Some graminicolous species of Helminthosporium and Curvularia in South Africa. - Bothalia 6: 347-378.

RaININKo, K. 1968: The effect of nitrogen fertilization, irrigation and number of harvestings upon leys established with various seed mixtures. - Acta Agralia Fennica 112: 1137.

Rapilly, F. 1964: Valeur taxonimique de 1lappareil sporifere du genue Helminthosporium Link. - Ann. Epiphyties 15: 257-268.

- \& Ponchet, J. 1962: Etude de quelques critères taxonomiques du genue Helminthosporium Link. - Ibid. 13: 293-300.

Rekola, O., Ruokola, A.-L. \& Kurtto, J. 1970 : 
Damage caused by Helminthosporium avenae Eidam on the crop yield of oats in Finland. - Acta Agric. Scand. 20: 225229.

Ritvanen, T. 1958: Timotein kuoriutuneiden siementen itävyyteen vaikuttavista tekijöistä. 155 pp. Unpublished. Licentiate study Helsinki University.

Rouvala, Y. 1967: Ohran viirutauti. - Maatalouden tutkimuskeskuksen tietokortti 5 B 14 .

Saccardo, P. A. 1886: Sylloge Fungorum IV. 807 pp. Patavii.

Salzmann, R. 1960: Tätigkeitsbericht der Eidg. Landwirtschaftlichen Versuchsanstalt Zürich-Oerlikon über das Jahr 1959. Landw. Jahrb. Schweitz N.S. 9: 667-744.

Sampson, K. \& Western, J. H. 1940: Two diseases of grasses caused by species of Helminthosporium not previously recorded in Britain. - Trans. Brit. Mycol. Soc. 24: 255-263.

- 1942: Diseases of British grasses and herbage legumes. - 85 pp. Cambridge.
Scharif, G. 1961: Studies on graminocolous species of Helminthosporium. - Trans. Brit. Mycol. Soc. 44: 217-229.

Shoemaker, R. A. 1959: Nomenclature of Drechslera and Bipolaris, grass parasites segregated from Helminthosporium. - Canad. J. Bot. 37: 879-886.

- 1962: Drechsilera Ito. - Ibid. 40: 809 836.

Smedegård-Petersen， V. 1970: Drechslera poae and Rhynchosporium orthosporum recorded as pathogens on grasses in Denmark. Horticultura 24: 38-46.

Sorokin, N. 1890: Uber einige Krankheiten der Kulturpflanzen im Süd-Ussurischen Gebiet. - In Trudy Obshch. Estest Imp. Kazan Univ., 22: 32. Abst. in Zeitsch. Pflanzenkrankh. 1: 236-239. 1891.

Sprague, R. 1950: Diseases of cereals and grasses in North America. - 538 pp. New York.

Reseived 20. XII. 1970

Printed III. 1997 